\title{
Idiosyncratic Volatility, Momentum, Liquidity, and Expected Stock Returns in Developed and Emerging Markets
}

\author{
Lorne N. Switzer* \\ Concordia University, Canada \\ Alan Picard \\ Concordia University, Canada
}

This paper re-examines the link between idiosyncratic risk and expected returns for a large sample of firms in both developed and emerging markets. Recent studies using Fama-French three-factor models have shown a negative relationship between idiosyncratic volatility and expected returns for developed markets. This relationship has not been studied to date for emerging markets. This study relates the current-month's idiosyncratic volatility to the subsequent month's stock returns for a sample of both developed and emerging markets expanding benchmark factors by including both a momentum and a systematic liquidity risk component. Using a five-factor model, the results suggest that idiosyncratic risk does not play a role on stock returns for most of the developed markets analyzed. In contrast, the paper shows, for the first time, that idiosyncratic risk is positively related to month-ahead expected returns for many emerging markets for this model. (JEL: G11, G12, G15)

Keywords: idiosyncratic volatility; expected returns; developed vs. emerging markets; asset pricing; multifactor models

Article history: Received: 25 June 2014, Received in final revised form: 10 February 2015, Accepted: 18 February 2015, Available online: 23 October 2015

\footnotetext{
${ }^{*}$ Corresponding author. tel.: 514-848-2424,x2960; E-mail:1orne.switzer@concordia.ca We would like to thank the editor, Panayiotis C. Andreou and three anonymous referees for their valuable comments and suggestions. The usual disclaimer applies. Financial support from SSHRC and the Autorité des Marchés Financiers to Switzer is gratefully acknowledged.
}

(Multinational Finance Journal, 2015, vol. 19, no. 3, pp. 169-221)

(C) Multinational Finance Society, a nonprofit corporation. All rights reserved. DOI: $10.17578 / 19-3-2$ 


\section{Introduction}

The seminal papers that introduced the foundations of modern portfolio theory (MPT) (Markowitz (1952); Sharpe (1964); Lintner(1965)) assert that, within the framework of the Capital Asset Pricing Model (CAPM), idiosyncratic risk should not be priced as long as representative agents hold the market portfolio or a well-diversified portfolio. Further theoretical extensions have looked at the effects of risk tolerance, information, and transactions costs in establishing a premium for idiosyncratic volatility (e.g. Levy (1978), Merton (1987), Jones and Rhodes-Kropf (2003), and Malkiel and Xu (2006)).

While the theoretical arguments for an idiosyncratic risk premium are relatively straightforward, the empirical evidence for such a premium is mixed, based on Fama-French type factor models. For example, Fu (2009) provides evidence that high idiosyncratic risk portfolios generate higher returns than low idiosyncratic risk portfolios for the US market. Ang et al. (2006) using monthly data document a negative idiosyncratic effect in US stock markets during the period 1963 to 2000 while Ang et al. (2009) also find a negative idiosyncratic risk effect in 22 developed markets (1980-2003).

This study contributes to the literature by analyzing the behaviour of idiosyncratic risk for an international sample consisting of both developed markets as well as, for the first time, emerging markets stock markets using a five-factor model that incorporates both momentum and liquidity risk. The latter might be deemed of particular importance for emerging markets since poor liquidity is often mentioned as one of the main reasons that prevent foreign investors from investing in emerging markets.

A positive relationship between idiosyncratic volatility and expected returns could imply that some potential risk factors that are not incorporated in the factor models employed in this study are not or may not be completely diversifiable and may hence generate the pricing of idiosyncratic volatility. The international finance literature distinguishes between three categories of non-diversifiable risk factors inherent to emerging markets.

a) Direct barriers that discriminate against foreign shareholders which could include ownership restrictions and onerous taxes (see e.g. Stulz (1981)).

b) Indirect barriers - this would include lack of transparency due to 
poor accounting standards, low investor protection (poor corporate governance), high transaction costs, and government expropriation of productive assets (e.g. Carrieri, Chaieb, and Errunza (2013)). Lack of transparency may also be linked to informational inefficiencies. For example, Bhattacharya et al. (2000) show that in emerging markets, insider trading often occurs well before the release of information to the public. Stock prices in such markets respond before public announcements, which is consistent with information leakage. In addition, the price response of shares traded by foreigners lags the price response of shares traded by locals. Another indirect barrier would be related to higher levels of corruption within emerging markets compared to developed markets (Switzer and Tahaoglu (2015)). Many emerging markets may also be prone to agency problems resulting from multilevel (pyramid) ownership structures that facilitate expropriation of the firm's resources by controlling shareholders (Shleifer and Vishny (1997), Lins (2003)). Shareholder rights are generally weak and takeovers are seldom used as an external disciplining governance mechanism (La Porta et al. (1998), Denis and McConnell (2003)).

c) Barriers that result from emerging market specific risks - Clark and Tunaru (2001) for example provide a model that measures the impact of political risk on portfolio investment. They define political risk as the volatility of the exposure of a portfolio to loss in the case of an explicit political event in a given country. Novel feature of their model is that political risk is multivariate and may be correlated across countries. Bekaert et al. (1997) suggest that political risk is priced in several emerging markets. Other emerging market specific risks would also include economic policy risk, and currency risk that dissuade foreign investment. Bartram, Brown and Stulz (2012) provide further insight into market specific factors that may be associated with differences in idiosyncratic volatility between emerging markets and developed markets. They distinguish between "good" volatility (e.g. due to patents, firm-level R\&D investment) from "bad" volatility (e.g. linked to political risk and poor disclosure). They conclude that emerging markets are more prone to "bad" volatility factors, relative to developed markets. ${ }^{1}$

1. They estimate idiosyncratic volatility as the standard deviation of error term from a systematic risk model that explains the return of a stock with the return of its country's market, the world market, and Fama-French size and value factors. Given the high 
While Bartram, Brown and Stulz (2012) highlight factors likely associated with good or bad volatility, they do not explore whether or not idiosyncratic volatility per se is priced in the different markets considered. This paper provides new evidence on this score. The analysis uses both the Carhart (1997) four-factor model as well as a five-factor model that incorporates the Amihud (2002) liquidity factor in the estimation of idiosyncratic risk. Using a five-factor model, the results suggest that idiosyncratic risk does not play a role on stock returns for most of the developed markets analyzed. In contrast, the results show, for the first time, that idiosyncratic risk is positively related to month-ahead expected returns for many emerging markets for this model.

Hence this paper presents evidence that the idiosyncratic puzzle found by Ang et al. (2009) in developed markets may be sample period specific. Indeed the negative relationship between expected returns and idiosyncratic volatility, estimated using the Fama-French three-factor model, discovered by Ang et al. (2009) for the period 1980 to 2003 disappears once the sample period is extended to December 2012. The non-existence of the idiosyncratic puzzle observed in this paper corroborates previous papers that have shown the weak evidence of such relationship. For instance, Wei and Zhang (2005) show that a trading strategy based on idiosyncratic volatility does not generate any significant profits in the US stock market during the period 1962 to 2000. Bali et al. (2005) demonstrate that there is no time series relation between idiosyncratic volatility and following stock returns because this relationship is not robust through time, as they show that neither idiosyncratic volatility nor stock market volatility forecasts stock market returns.

Moreover the positive link between idiosyncratic volatility and subsequent monthly returns observed in emerging markets, which rejects the idea of an idiosyncratic puzzle, would be expected according to Levy (1978) and Merton (1987) who assert that investors demand a return compensation for bearing idiosyncratic risk caused particularly by factors that may not be diversifiable. Bartram, Brown and Stulz (2102) enumerate several such risk factors inherent to emerging markets e.g. political risk, liquidity risk, lack of transparency due to poor

correlations between US and developed market returns and the world market returns, the standard errors of their estimates may be higher than for emerging markets, which could distort the significance of the idiosyncratic volatility factor. This problem is highlighted in Girard and Sinha (2006) who show that unlike developed markets, emerging markets are sensitive to local, but not global risk factors. 
accounting standards and informational inefficiencies and low investor protection.

In order to estimate idiosyncratic volatility, the four-factor model, which is an extension to the Fama-French three-factor model by adding a momentum factor, and the five-factor model, which incorporates a liquidity risk factor to the previous model, are employed. A liquidity risk factor is included in this study since it is generally recognised that liquidity is important for asset pricing and that systematic variation in liquidity matters for expected returns: Since rational investors require a higher risk premium for holding illiquid securities, these assets and assets with high transaction costs are characterized by low prices relative to their expected cash flows i.e. average liquidity is priced (Amihud and Mendelson (1986); Brennan and Subrahmanyam (1996); Chordia, Roll and Subrahmanyam (2001)). For instance, Haugen and Baker (1996) document that the liquidity of stocks is one of several common factors in explaining stock returns across global markets. Amihud, Mendelson, and Lauterbach (1997) show that enhancement in liquidity on the Tel Aviv Stock Exchange is linked to price increases.

This paper examines the issue of liquidity for developed countries but as well as for a set of markets where liquidity ought to be particularly important i.e. emerging markets. Two reasons show that laying emphasis on illiquidity is critical for emerging markets due to their limited access to global capital markets. Firstly, returns in emerging countries may be adversely affected by the increased illiquidity of trading stocks relative to returns in more developed markets. Secondly Bekaert, Harvey and Lundblad (2007) show results suggesting that local market liquidity is an important driver of expected returns (liquidity is a priced factor), much more so than local market risk, in emerging markets and that model specifications that incorporate liquidity risk outperform other models that only consider market risk factors in predicting future returns. Moreover Bekaert, Harvey and Lundblad (2007) document that higher political risk and weak law and order conditions could act as segmentation indicators and that liquidity may further affect expected returns in countries with these aspects. The authors explain that liquidity effects are relatively small in a developed country such as the United States since its market is large in the number of traded securities and because it has a very diversified ownership structure i.e. a stock market categorized by both long-horizon investors, less prone to liquidity risk, and short-term investors. Hence, in the United States clientele effects in portfolio choice alleviate the pricing of liquidity while such variety in securities and ownership is deficient 
in emerging markets, potentially reinforcing liquidity effects. Lesmond (2005) corroborates Bekaert, Harvey and Lundblad's (2007) findings by investigating the impact of legal origin and political institutions on liquidity levels provide evidence that countries with poor political and legal systems and organizations have considerably greater liquidity costs than do countries with solid and strong political and legal institutions. Higher incremental political risk translates into a $1.9 \%$ increase in price impact costs employing the Amihud measure.

The remainder of this study is organized as follows. In the next section, a review of the literature is presented. An introduction of the data used in this paper and a description of the research methodology is provided in section III. The empirical results follow in section IV. The paper concludes with a summary in section V.

\section{Literature Review}

Idiosyncratic volatility has been a topic of considerable interest in the literature since the seminal contributions of Levy (1978) and Merton (1987) and the empirical results of Campbell et al. (2001) that show a secular increase in idiosyncratic volatility over a long horizon. Merton (1987) argues that to the extent that investors cannot create portfolios that contain only systematic risk they demand a return compensation for bearing idiosyncratic risk: the less diversified the portfolios, the higher the proportion of idiosyncratic risk impounded into expected returns making high idiosyncratic stocks earn more than low idiosyncratic stocks - i.e. idiosyncratic risk should be positively related to stock returns. However, no consensus has emerged on the actual effects of idiosyncratic volatility on the cross-sectional variation in stock returns. Some studies have found a positive relationship, consistent with Merton (1987). Others have shown either no relationship or even a negative relationship between idiosyncratic risk and stock returns.

\section{A. Positive relationship between idiosyncratic volatility and stock returns}

Malkiel and Xu (1997) form portfolios of US stocks based on idiosyncratic volatility and show a positive relationship between idiosyncratic volatility and the cross-section of monthly future stock returns. Goyal and Santa-Clara (2003) also find that average stock 
idiosyncratic volatility is positively related to value-weighted market returns. Similar results are shown by Wei and Zhang (2005), and Pukthuanthong-Le and Visaltanachoti (2009). Fu (2009) shows that forecasts of idiosyncratic volatility based on exponential generalized autoregressive conditional heteroskedasticity (EGARCH) models are positively related to returns from 1963 to 2006. Bainbridge and Galagedera (2009) show evidence of a positive relationship between idiosyncratic volatility and expected stock returns for Australian stocks. Ben-David, Franzoni and Moussawi (2012) present evidence that hedge funds generate higher returns from trading high idiosyncratic risk stocks rather than low idiosyncratic risk stocks. Nartea, Ward, and Yao (2011) show a positive relationship between idiosyncractic volatility and expected stock returns in four Southeast Asian stock markets (i.e. Singapore, Malaysia, Indonesia, and Thailand) during the period from the early 1990s to the end of 2007. More recently, Brooks, Li, and Miffre (2013) show that cross-sectional returns are positively related to differences in the unsystematic risk of portfolio returns. Their finding is that idiosyncratic risk is priced. In sum, these papers are in line with the notion that agents who fail to fully diversify their portfolios demand higher average returns to compensate them for bearing higher levels of firm-specific risk (Merton (1987)).

\section{B. Negative relationship between idiosyncratic volatility and stock returns}

Ang et al. (2006) provide empirical evidence suggesting that U.S. stocks with higher lagged idiosyncratic volatility have abnormally lower equally-weighted returns, a phenomenon which they call "the idiosyncratic risk puzzle." The authors report that the average return differential between the lowest and highest quintile portfolios formed on one-month lagged idiosyncratic volatilities is about $-1.06 \%$ per month for the period 1963-2000. In their paper, idiosyncratic volatility is measured as the standard deviation of the residuals of the daily three-factor Fama and French (1993) model over the prior month. Guo and Savickas (2006) show that value-weighted idiosyncratic volatility is negatively and significantly related to subsequent quarterly excess stock market returns, for G7 countries using quarterly data over the period 1963 to 2002. Chang and Dong (2006) document a negative relationship between idiosyncratic volatility and expected stock returns in the Japanese stock market from 1975 to 2002. Koch (2010) finds that 
low idiosyncratic volatility stocks generate higher returns than high idiosyncratic volatility stocks in the German stock market from 1974 to 2006.

\section{No relationship between idiosyncratic volatility and stock returns}

Wei and Zhang (2005) demonstrate that a trading strategy based on idiosyncratic volatility does not yield any significant economic gains using US stock market data over the period 1962 to 2000. Bali et al. (2005) argue that the findings of Goyal and Santa-Clara (2003) that the average idiosyncratic risk is positively related to future returns are not robust through time. They conclude that there is no time series relation between diversifiable risk and subsequent stock returns, as they show that neither idiosyncratic volatility nor stock market volatility forecasts stock market returns in an extended sample ending in 2001. Bali and Cakici (2008) state that the relationship between idiosyncratic volatility and the cross-section of stock returns largely depends on the data frequency used to compute asset-specific volatility. Nartea and Ward (2009) report that there is no association between diversifiable volatility and expected stock portfolio returns in the Philippine stock market.

Huang et al. (2010) suggest that the disparate results for Bali and Cakici (2008) and Ang et al. (2009) can be explained by short term monthly return reversals - which could confound the results of conventional three or four-factor models of expected returns. On balance, they suggest that no relationship between idiosyncratic return and risk should be observed once return reversals are accounted for.

In a recent paper, Fan, Opsal, and Yu (2015) show that idiosyncratic risk across several international equity markets is correlated with abnormal returns associated with a wide array of stock market anomalies, including asset growth, book-to-market, investment-to-assets, momentum, net stock issues, size, and total accruals, in international equity markets. They find that idiosyncratic risk has less impact on abnormal returns associated with anomalies in developed countries than on emerging countries. However, they do not look at how idiosyncratic returns are associated with expected returns per se.

In sum, the evidence to date concerning the relationship between idiosyncratic volatility and stock returns remains ambiguous. Furthermore, most existing empirical research focuses on US stock markets, and is based on simple applications of basic factor models (e.g. 
the one factor model or the three-factor Fama-French (1993) model), or time series approaches (such as GARCH) that are not directly linked to asset pricing models. This paper looks to extend our understanding of the role of idiosyncratic risk and volatility by a) providing more recent evidence from other developed and emerging stock markets; and b) using further extensions to the Fama-French (1993) model that may improve the measurement of idiosyncratic risk.

\section{Data and Methodology}

This study uses stock market daily returns on firms from 23 developed and 15 emerging markets: Argentina, Australia, Austria, Belgium, Brazil, Canada, Denmark, Finland, France, Germany, Greece, Hong Kong, India, Indonesia, Ireland, Israel, Italy, Japan, Korea, Malaysia, Mexico, the Netherlands, New Zealand, Norway, Philippines, Poland, Portugal, Russia, Singapore, South Africa, Spain, Sweden, Switzerland, Taiwan, Thailand, Turkey, the UK and the US. Non-US firm returns are collected from the Thompson Financial Datastream for the sample period January 1980 to December 2012. US stock returns are obtained from CRSP. Because the Czech Republic, which was initially included in the sample, never reaches the threshold of 30 stocks during the sample period analysed this country is removed from the study. We consider the returns from local investor or currency hedged foreign investor perspectives by studying local-currency denominated returns for the analyses, with excess returns computed using each country 1-month or 3-month T-Bill rates. ${ }^{2}$ As per Ang et al. (2009), in all non-U.S. countries, we exclude very small firms by eliminating the $5 \%$ of firms with the lowest market capitalizations. The number of stocks included and the coverage period for each country are shown in table 1. A set of illustrative stocks in various countries used in the analyses is provided in appendix $1 .^{3}$

2. For nations in which the 1-month or 3-month T-Bill rates are not available the 1 month U.S. T-Bill rate was used as per Ang et al. (2009). Note also that for countries in which the 1-month or 3-month T-Bill rates were obtainable, idiosyncratic volatilities were computed twice using both local rates and the 1-month U.S. T-Bill rate giving similar results for each country.

3. A complete listing of stocks for all countries used in the analyses is available on request. 
TABLE 1. Description of Sample: Distribution of Stocks by Country

\begin{tabular}{|c|c|c|c|c|}
\hline Country & Start & $\mathrm{N}($ Start $)$ & End & $\mathrm{N}($ End $)$ \\
\hline \multicolumn{5}{|l|}{ G7 Countries } \\
\hline Canada & Jan 1980 & 32 & Dec 2012 & 233 \\
\hline France & Jan 1980 & 34 & Dec 2012 & 233 \\
\hline Germany & Jan 1980 & 47 & Dec 2012 & 233 \\
\hline Italy & Jun 1986 & 35 & Dec 2012 & 149 \\
\hline Japan & Jan 1980 & 319 & Dec 2012 & 916 \\
\hline United Kingdom & Jan 1980 & 388 & Dec 2012 & 911 \\
\hline United States & Jan 1980 & 1978 & Dec 2012 & 3788 \\
\hline \multicolumn{5}{|c|}{ Developed Markets } \\
\hline Australia & Jan 1984 & 30 & Dec 2012 & 152 \\
\hline Austria & Jun 1999 & 30 & Dec 2012 & 46 \\
\hline Belgium & Jun 1986 & 30 & Dec 2012 & 83 \\
\hline Denmark & Jun 1992 & 30 & Dec 2012 & 42 \\
\hline Finland & Jul 1994 & 30 & Dec 2012 & 46 \\
\hline Greece & Jul 1998 & 30 & Dec 2012 & 47 \\
\hline Hong Kong & Jun 1988 & 35 & Dec 2012 & 122 \\
\hline Ireland & Dec 2007 & 30 & Dec 2012 & 30 \\
\hline Netherlands & Jan 1980 & 34 & Dec 2012 & 105 \\
\hline New Zealand & Sep 1999 & 30 & Dec 2012 & 45 \\
\hline Norway & Jun 2001 & 30 & Dec 2012 & 47 \\
\hline Portugal & Jun 1998 & 30 & Dec 2012 & 46 \\
\hline Singapore & Feb 1989 & 30 & Dec 2012 & 93 \\
\hline Spain & Jun 1999 & 30 & Dec 2012 & 46 \\
\hline Sweden & Aug 1991 & 30 & Dec 2012 & 66 \\
\hline Switzerland & Jul 1980 & 30 & Dec 2012 & 133 \\
\hline \multicolumn{5}{|l|}{ Emerging Markets } \\
\hline Argentina & Jan 1995 & 30 & Dec 2012 & 50 \\
\hline Brazil & Oct 1994 & 30 & Dec 2012 & 97 \\
\hline India & Nov 1994 & 93 & Dec 2012 & 198 \\
\hline Indonesia & Jun 1998 & 30 & Dec 2012 & 50 \\
\hline Israel & Jun 1996 & 30 & Dec 2012 & 50 \\
\hline Korea & May 1987 & 31 & Dec 2012 & 97 \\
\hline Malaysia & Jan 1986 & 30 & Dec 2012 & 89 \\
\hline Mexico & Mar 1993 & 30 & Dec 2012 & 84 \\
\hline Philippines & Nov 1994 & 30 & Dec 2012 & 50 \\
\hline Poland & Apr 2005 & 30 & Dec 2012 & 50 \\
\hline Russia & Jan 2007 & 30 & Dec 2012 & 47 \\
\hline South Africa & Jan 1990 & 34 & Dec 2012 & 70 \\
\hline Taiwan & Nov 1994 & 30 & Dec 2012 & 70 \\
\hline Thailand & Aug 1994 & 30 & Dec 2012 & 50 \\
\hline Turkey & Apr 1997 & 30 & Dec 2012 & 49 \\
\hline
\end{tabular}

Note: This table presents data coverage of the G7 countries, 16 developed markets and 15 emerging markets. N(start) and $\mathrm{N}$ (end) show the number of stocks at the starting and ending sample period. 


\section{A. Estimating idiosyncratic volatilities}

This paper uses an intertemporal approach in which lagged monthly idiosyncratic volatility is related to monthly returns. Ang et al. (2006, 2009) measure idiosyncratic risk by realized idiosyncratic volatility using a local version of the Fama and French (1993) three-factor model (1). The idiosyncratic volatility of a stock in each month is the standard deviation of the regression residuals $\varepsilon_{i}$ :

$$
r_{i}=\alpha_{i}+\beta_{i} M K T+s_{i} S M B+h_{i} H M L+\varepsilon_{i}
$$

where $r_{i}$ is the daily excess returns of stock $i, \alpha_{i}$ is the Fama-French adjusted alpha, $M K T$ is the excess return on the market portfolio in each country defined as the value-weighted average of all stocks; $S M B$ (small minus big market capitalization) and $H M L$ (high minus low book-to-market) are return differences between the top 33.33 percent and bottom 33.33 percent ranked stocks in each country respectively; $\beta_{i}$, $s_{i}$ and $h_{i}$ are the estimated factor exposures. Griffin (2002) provides evidence that the Fama and French factors are country specific and concludes that the three-local factor Fama-French model provides a better explanation of time-series variation in stock returns for international stocks than a global factor model.

This study extends the three-factor model by adding two additional factors to estimate idiosyncratic volatilities: a momentum factor and an illiquidity factor. We perform the analyses using both the Carhart (1997) model (equation (2)) that incorporates momentum, as well as a five-factor model (equation (3)) that includes an illiquidity premium as well:

$$
\begin{gathered}
r_{i}=\alpha_{i}+\beta_{i} M K T+s_{i} S M B+h_{i} H M L+m_{i} M O M+\varepsilon_{i} \\
r_{i}=\alpha_{i}+\beta_{i} M K T+s_{i} S M B+h_{i} H M L+m_{i} M O M+l_{i} I M L+\varepsilon_{i}
\end{gathered}
$$

Analogous to the size $(S M B)$, and the book-to-market $(H M L)$ return proxies, the momentum factor $(M O M)$ is constructed as the equal-weighted average of firms with the highest 33.33 percent eleven-month returns lagged one month minus the equal-weighted average of firms with the lowest 33.33 percent eleven-month returns lagged one month (Carhart (1997)).

The illiquidity premium denoted $I M L$ (illiquid-minus-liquid portfolio 
return) is the difference between the average excess return on high-illiquidity stocks (33.33 percent highest) and low-illiquidity stocks (33.33 percent lowest). In this study the proxy used for illiquidity is the "price impact"illiquidity measure proposed by Amihud (2002). This measure captures the response associated with one dollar of trading volume. More specifically, the illiquidity factor is computed as the daily ratio of absolute stock return to dollar volume:

$$
\text { Illiq }_{i}=\frac{\left|r_{i}\right|}{D V O L_{i}}
$$

where $r_{i}$ is a daily stock return of stock $i$, and $D V O L_{i}$ is daily dollar volume.

We use the illiquidity measure proposed by Amihud (2002) since it is one of the most widely used in the finance literature. This popularity is due to two advantages it has over many other liquidity measures. First, the measure can be easily constructed using daily stock data. Second, the measure shows a strong positive relationship with a high-frequency price impact measure and expected stock return (e.g. Amihud (2002), and Chordia, Huh, and Subrahmanyam (2009)).

The trading strategy based on idiosyncratic volatility involves portfolios formation based on an estimation period of $\mathrm{L}$ months, a waiting period of $\mathrm{M}$ months, and a holding period of $\mathrm{N}$ months. The $\mathrm{L} / \mathrm{M} / \mathrm{N}$ strategy is defined as follows. At month $t$, idiosyncratic volatilities from regressions (3) and (4) on daily data over an L-month period from month $\mathrm{t}-\mathrm{L}-\mathrm{M}$ to month $\mathrm{t}-\mathrm{M}$ are measured. At time $t$, portfolios based on these idiosyncratic volatilities are formed and held for $\mathrm{N}$ months. In this study, the analysis focuses on the 1/0/1 strategy, in which stocks are sorted into quintile portfolios based on their level of idiosyncratic volatility estimated using daily returns over the previous month, and held for 1 month. The portfolios are reformed at the beginning of each month.

\section{Empirical Results}

Figure 1 provides graphs of the time variation of aggregate idiosyncratic volatility for the United States, G7 countries (except Italy), developed markets and emerging markets all depict no significant positive trend 


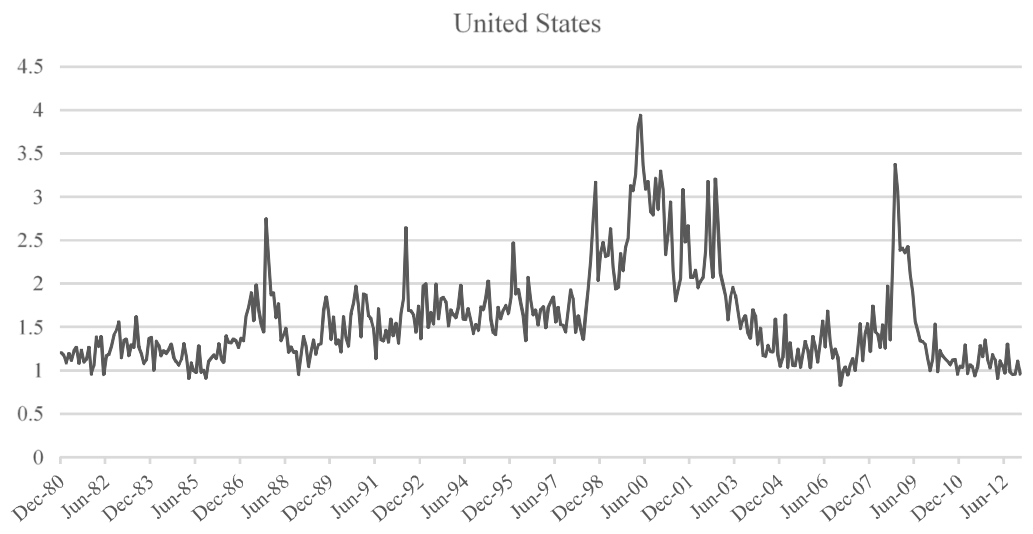

G7 Countries except Italy

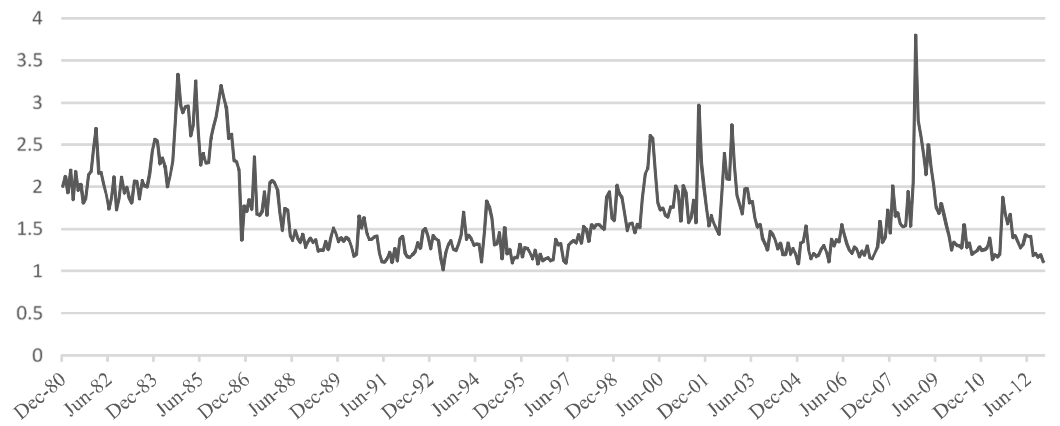

Developed Markets

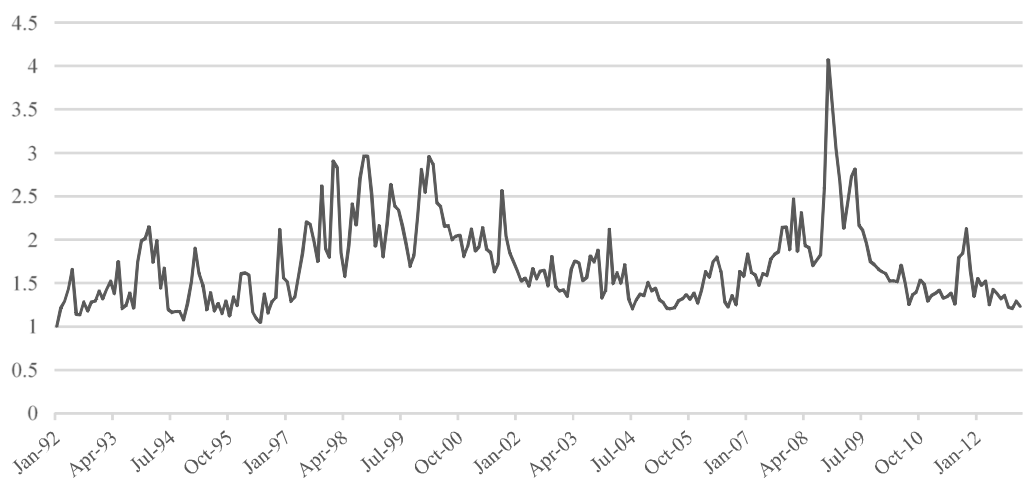




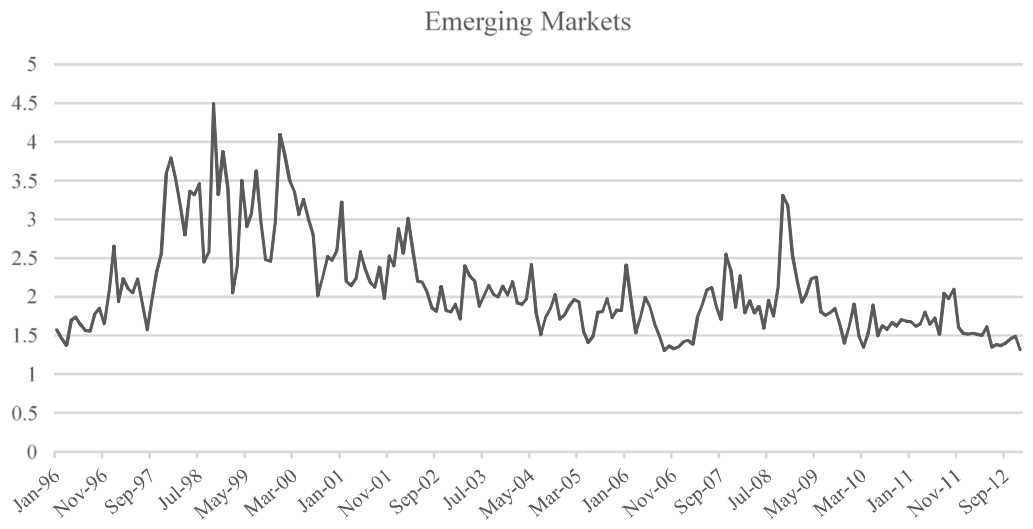

FIGURE 1.- Time Series Plots of Aggregate Monthly Idiosyncratic Volatility (\%) - based on four-factor model

Note: Developed Markets: Australia, Belgium, Denmark, Hong Kong, Netherlands, Singapore, Sweden and Switzerland. Emerging Markets: Argentina, Brazil, India, Korea, Malaysia, Mexico, Philippines, South Africa, Taiwan and Thailand.

over the full sample period.

The positive trend in idiosyncratic volatility observed by Campbell et al. (2001) for the period ending 1997 continues until June 2000, but is not clearly evident thereafter. It is also noteworthy that for the US, three out of the seven peaks in the aggregate levels of idiosyncratic volatility occur during the October 1987 crash, the March 2000 technology bubble burst, and the fall 2008 global financial crisis. Spikes in idiosyncratic volatility are also observed for other G-7 and developed markets as well as for emerging markets during March 2000 and Fall 2008.

Table 2 reports summary statistics for three different average volatility measures of stock returns across countries: idiosyncratic volatilities measured based on the four-factor model, the five-factor model, and total volatility which is computed as the volatility of daily raw returns over the previous month; the volatility measures are all annualized by multiplying by $\sqrt{250}$.

New Zealand has the lowest idiosyncratic volatility $(20.50 \%$ per annum based on the four-factor model and $19.08 \%$ using the five-factor model) while Ireland shows the highest idiosyncratic volatility $(42.87 \%$ 
per annum measured on the four-factor model and 39.99\% measured on the five-factor model). The average idiosyncratic volatilities for G7 Countries are $29.26 \%$ and $28.05 \%$ based on the four-factor and five-factor models respectively. The estimates of idiosyncratic volatility are lower for developed markets $(27.97 \%$ and $26.63 \%)$ but higher for emerging markets (30.45\% and $28.45 \%$ ), perhaps reflecting the direct and indirect barriers to foreign investors, as well as country specific risks that are of greater significance for emerging markets.

Tables 3 and 4 (tables 5 and 6) show the results for the returns of equal-weighted (value-weighted) portfolios sorted on past 1-month idiosyncratic volatility for all countries measured based on the five-factor and four-factor models respectively; Portfolio 1 (5) is the portfolio of stocks with the lowest (highest) volatilities.

A negative relationship between idiosyncratic volatility and portfolio future returns in each of the non-U.S. G7 countries (Panel A) is observed, using both equal- and value-weighted portfolios, consistent with Ang et al. (2009) for the full period from January 1980 to December 2012 (except for Italy which starts in June 1986). However, the US (equally-weighted) and the United Kingdom (value-weighted) are the only G7 countries that exhibit a positive relationship between asset-specific risk and expected monthly returns which contrasts with Ang et al. (2006, 2009).

However, two critical facts in these figures deserve attention. First none of the $\mathrm{G} 7$ countries display a monotonic idiosyncratic volatility -returns relationship across portfolios ranked from the lowest idiosyncratic risk portfolio (Quintile 1) to the highest (Quintile 5). Average returns decline from Quintile 1 to Quintile 2 for Canada, France, Germany, Italy and Japan and then increase as we move from portfolio 2 to portfolio 5, as is shown in appendix 2. Using equal-weighted portfolios, the difference of returns between Quintile 1 and Quintile 5 is significant for only three countries: France, Germany and Japan, amounting to $1.57,1.06$ and 1.24 percent per month respectively based on the five-factor model. ${ }^{4}$

For value-weighted portfolios, the results are even more attenuated: the relationships between idiosyncratic volatility and expected returns

4. The estimates are $1.60,1.04$ and 1.24 percent per month when diversifiable risk is estimated using the four-factor model, and are statistically significant at conventional levels. 


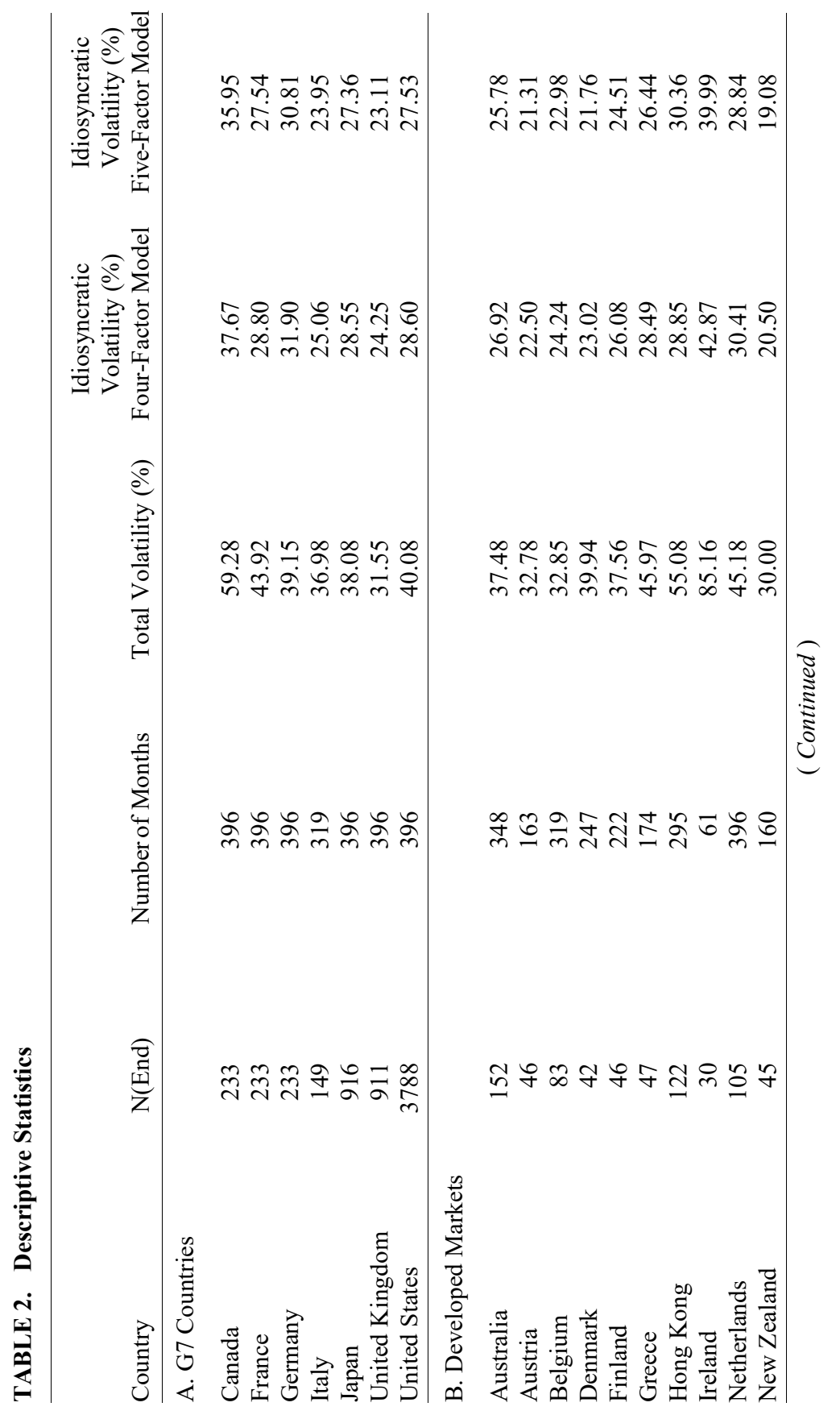


Idiosyncratic Risk and Expected Returns

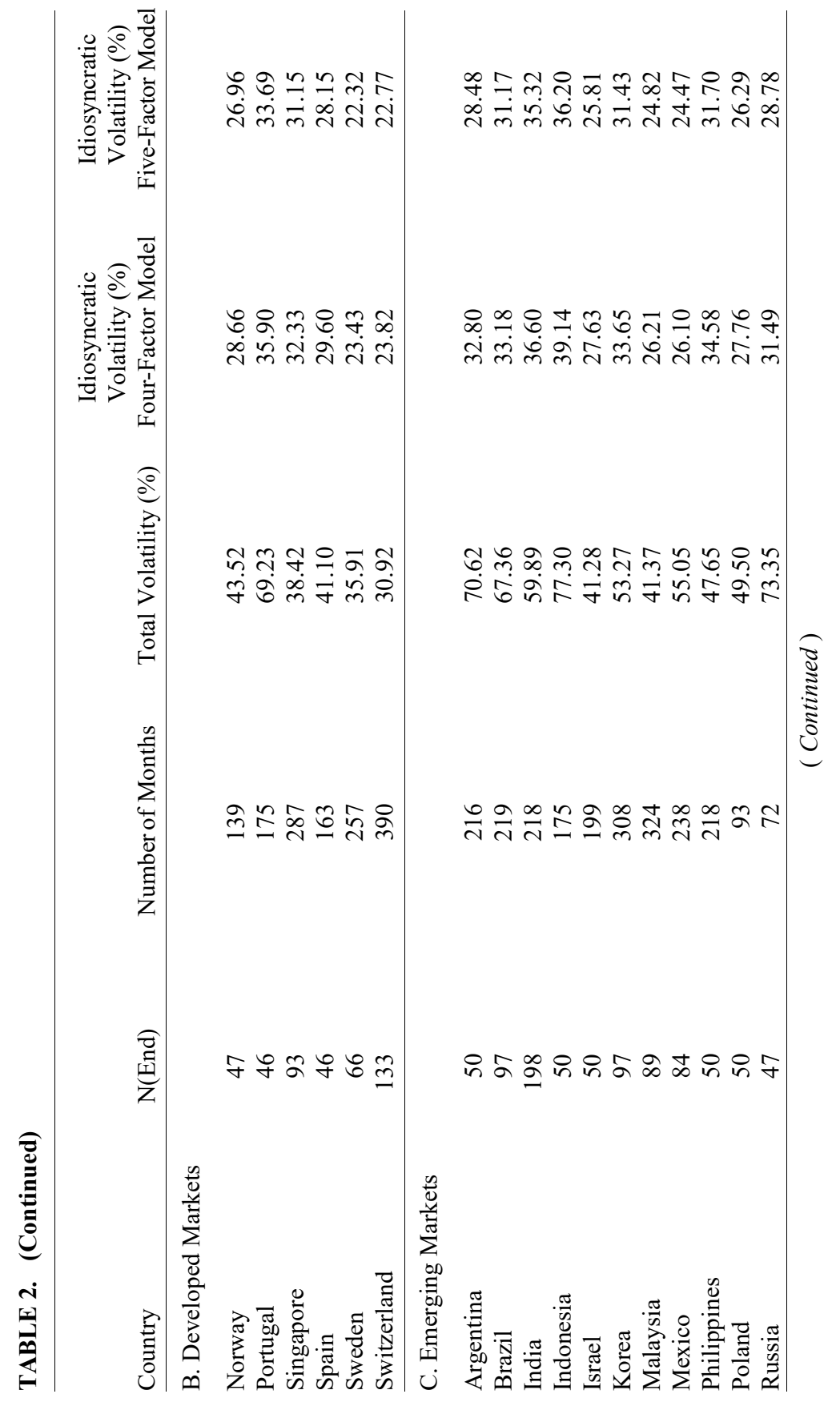




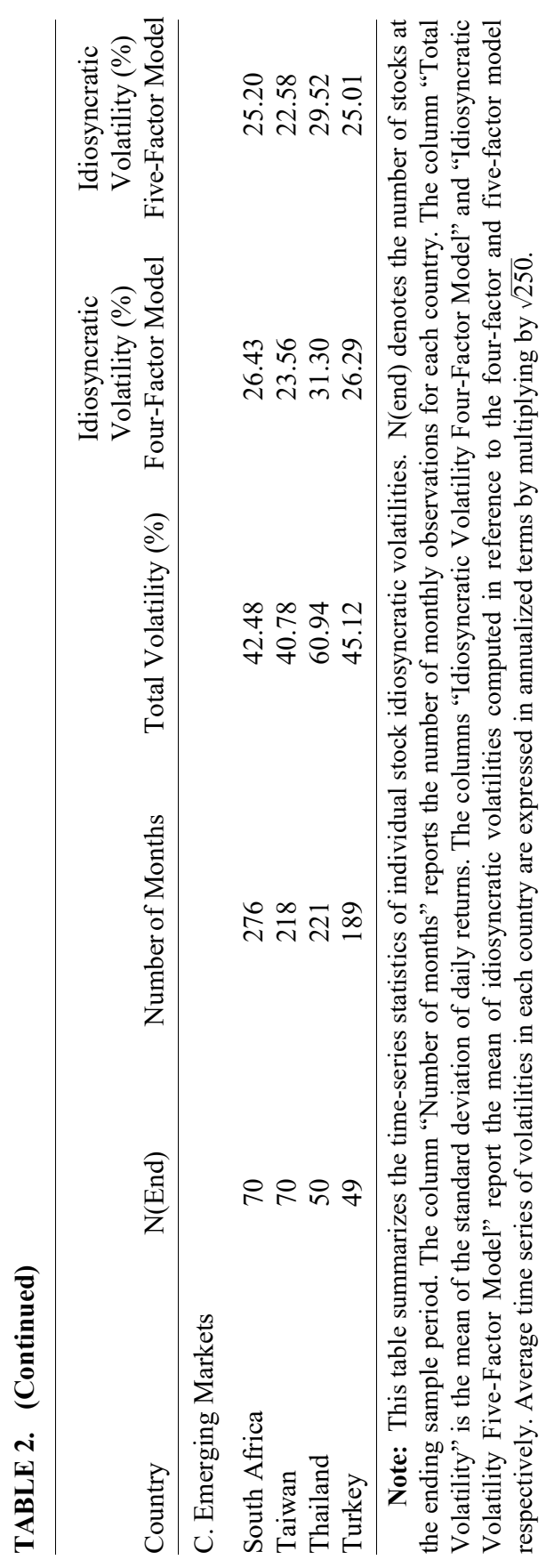


are weaker and only two countries: Canada and Germany show a statistically significant relationship when idiosyncratic volatility is measured based on the five-factor model. Germany appears to be the country with the most significant results amongst the G7 countries, and shows a monotonic (negative) relationship between idiosyncratic volatility and stock market return performance. The results are consistent with Koch (2010) who also shows that the idiosyncratic volatility puzzle in Germany cannot be explained by return reversals (as per Huang et al (2010)). Germany has long been known as having one of the most bank-based financial systems relative to other countries in the G-7. The relatively "thinner" equity market of German firms may in part explain the idiosyncratic volatility puzzle for Germany. Providing a more thorough rational explanation of this result remains a matter for future research, however.

Panels B of tables 3 to 6 display results for developed markets and provide mixed evidence on the relationship between idiosyncratic risk and monthly expected returns. Indeed, for equal-weighted portfolios, 5 (11) developed markets show a negative (positive) relationship between idiosyncratic volatility and monthly expected returns but none of the differences in mean are statistically significant. For value-weighted portfolios, the results remain almost identical: 2 (14) developed markets (when idiosyncratic volatity is estimated in respect to the five-factor model) and 5 (11) developed markets (when idiosyncratic volatity isestimated in respect to the four-factor model) suggest a negative (positive) relationship between idiosyncratic volatility and monthly expected returns. Moreover, as per the results regarding G7 countries, a monotonic relationship from Quintile 1 to Quintile 5 is not observed for any of the developed countries in the sample.

The results for emerging countries shown in Panel C of tables 3 to 6 , contrast with those of the G-7 and developed countries. While most of the G7 countries show a negative association between diversifiable risk and expected returns, emerging countries exhibit an opposite relation: 12 out of these 15 countries suggest a positive link between idiosyncratic risk and expected returns. Furthermore, contrary to both developed and G7 countries, with the exception of Israel, Russia, and Thailand, the relationship between returns and idiosyncratic volatility appears to be fairly linear. Whether estimating idiosyncratic volatility with the four or the five-factor model, the results in tables 3 to 6 show 


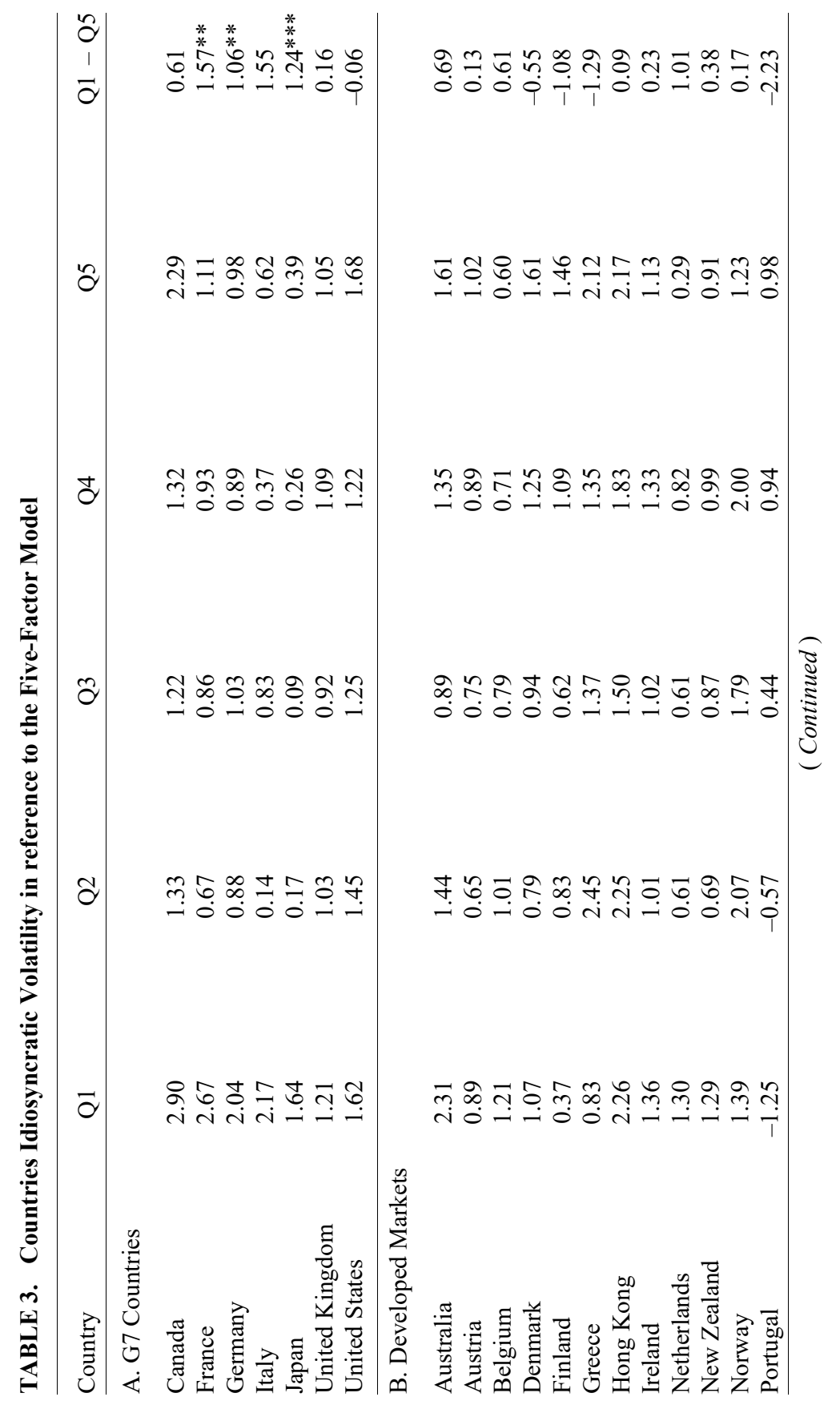




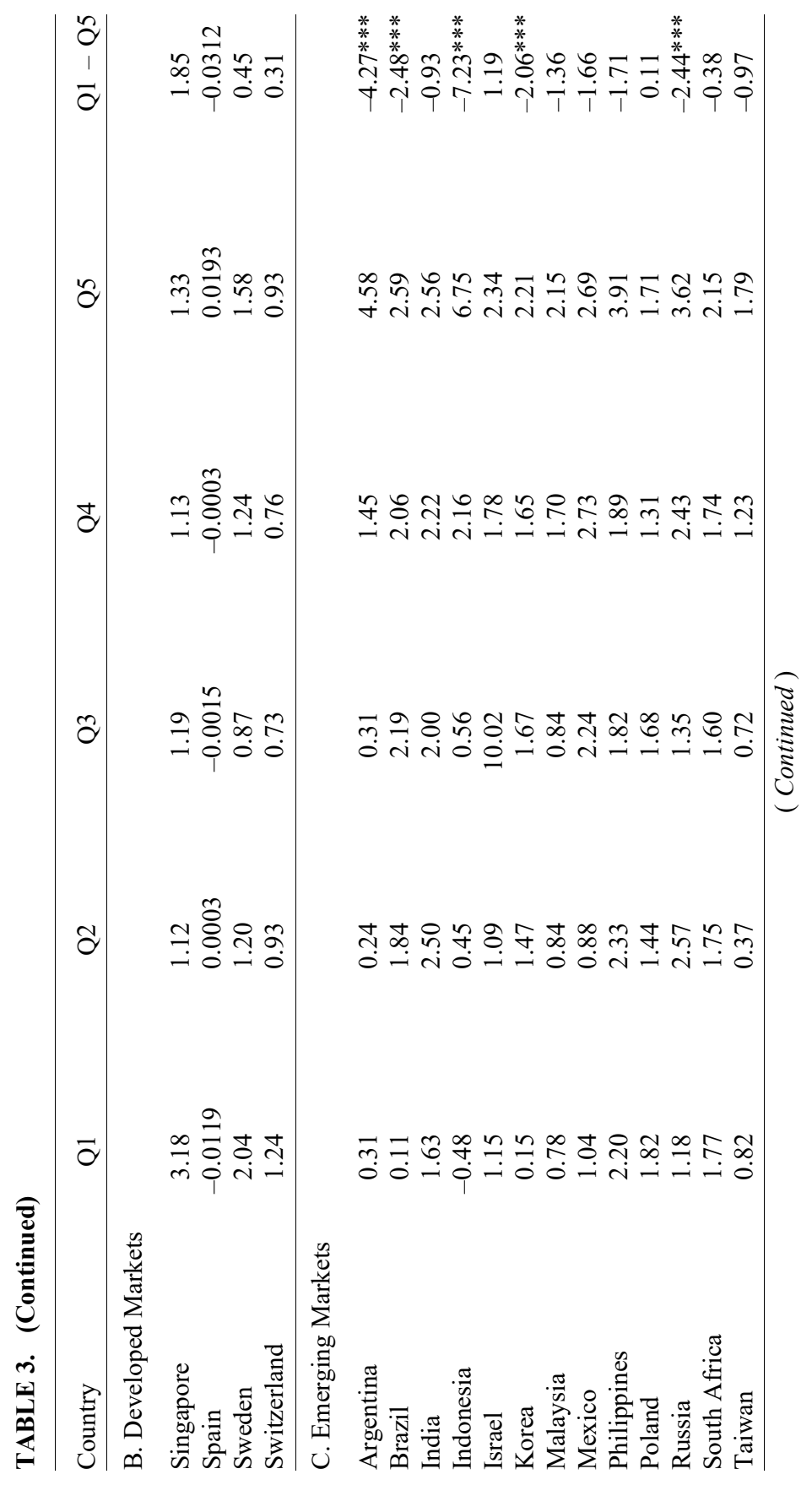




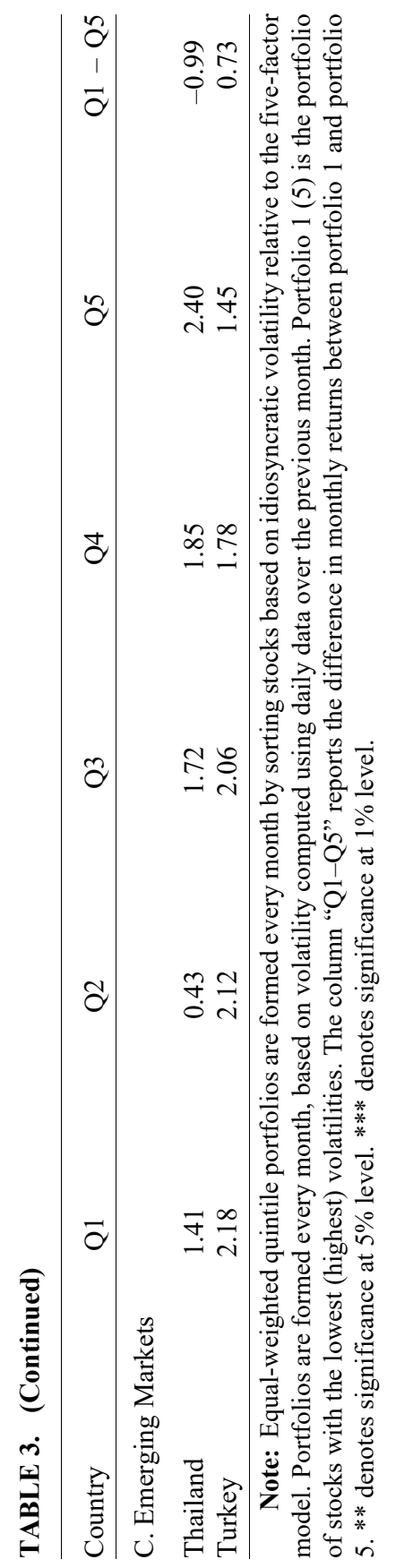




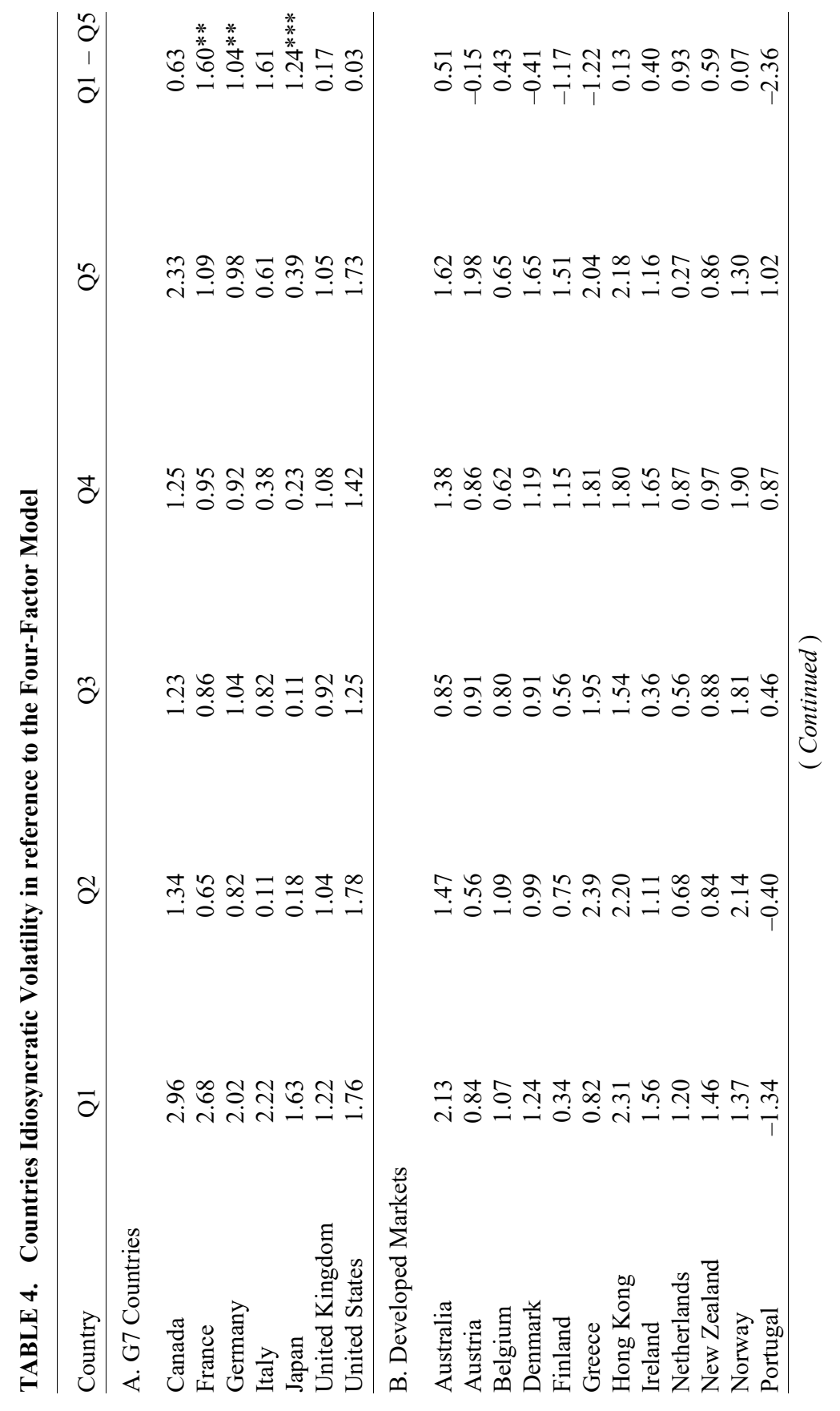


192 Multinational Finance Journal

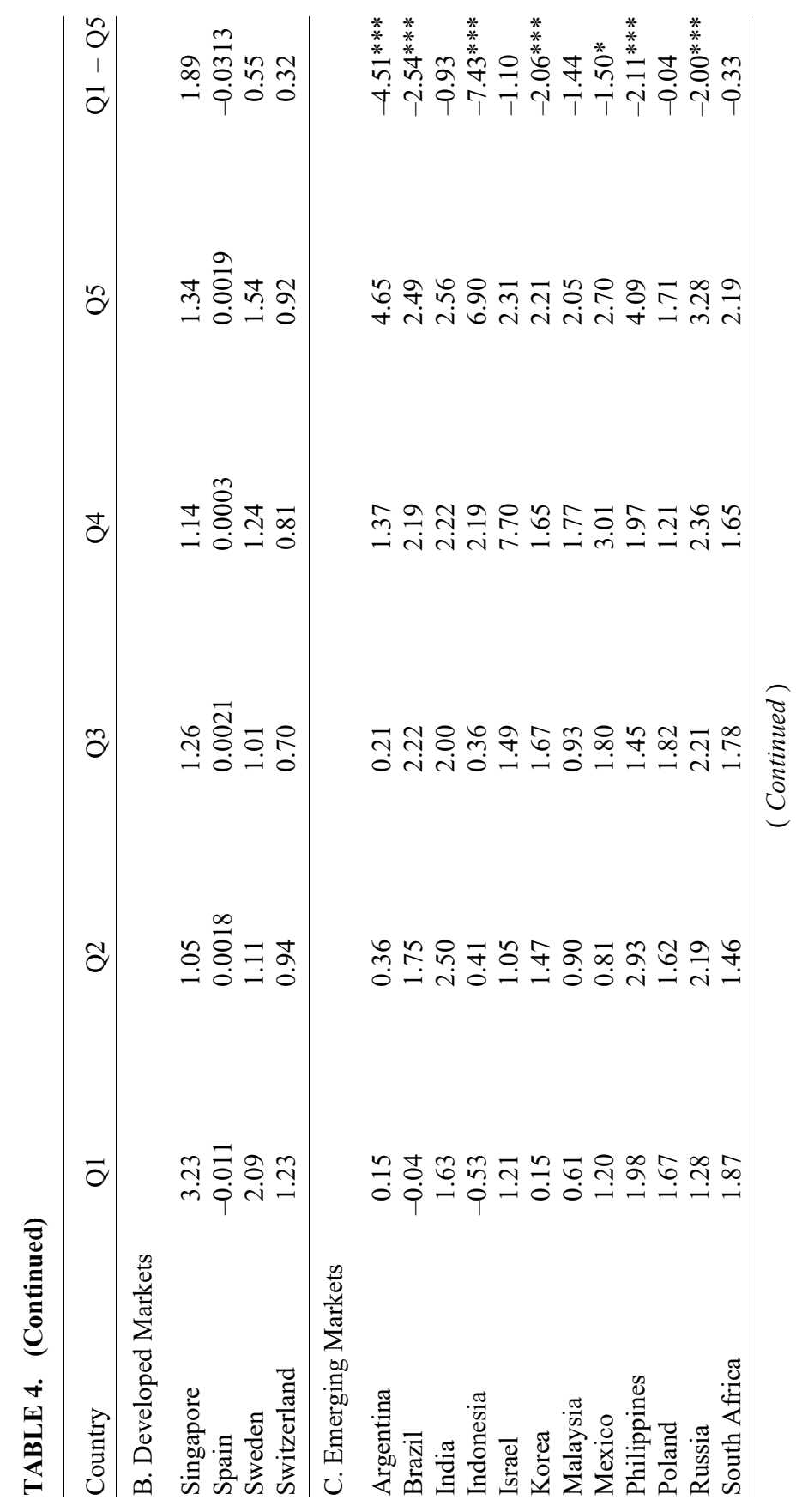




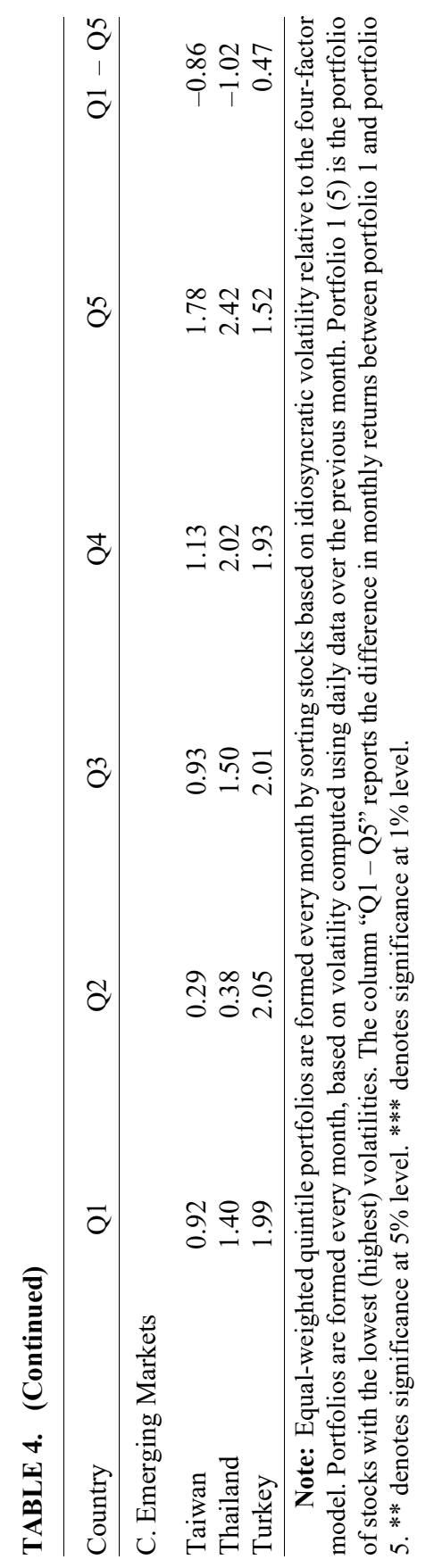


a strong and statistically significant difference in means (for both equaland value-weighted portfolios) between the two extreme quintiles for 5 out of the 15 emerging countries: Argentina, Brazil, Indonesia, Korea and Russia for equal-weighted portfolios and the same countries for value-weighted portfolios except that Russia is replaced by The Philippines.

One possible reason that the results differ between $\mathrm{G} 7$ countries and emerging markets could be because of differences in the level of portfolio diversification attained by investors. Indeed, the results for emerging countries corroborate theories assuming investor under-diversification caused by market frictions that prevent investing in fully diversified portfolios (Levy (1978), Merton (1987)); in such an environment investors request compensation for bearing idiosyncratic risk generating a positive relationship between idiosyncratic volatility and returns.

Other factors that could have affected differences between G7 countries and emerging markets results comprise differences in terms of degrees of financial liberalization (Umutlu, Akdeniz, and Altay-Salih (2010)), financial market development (Brown and Kapadia (2007)), and the degree of investor protection (Lemmon and Lins (2003); Cheng and Shiu (2007)).

Tables 7 and 8 report comparative results for portfolio returns when idiosyncratic volatility is computed using three-factor model for equaland value-weighted portfolios respectively. Again an overall similar pattern is observed when comparing these results with the ones derived from the four and five-factor models. Only 3 (equal-weighted) and 2 (value-weighted) out the G7 countries suggest a strong negative relationship between specific volatility and expected returns.

For developed markets, we also obtain similar general results when idiosyncratic volatility is estimated using the three, four and five-factor models: no statistically significant relationship is observed except for Australia (value-weighted portfolios). However it is interesting to notice that 9 out of the 16 countries show a negative relationship for the value-weighted portfolios but only 4 out of these same countries suggest the same direction of relationship for equal-weighted portfolios. Note that in their paper, Ang et al. (2009) employ the three-factor model as well as value-weighted portfolios to obtain a negative association between idiosyncratic volatility and expected returns for G7 and 


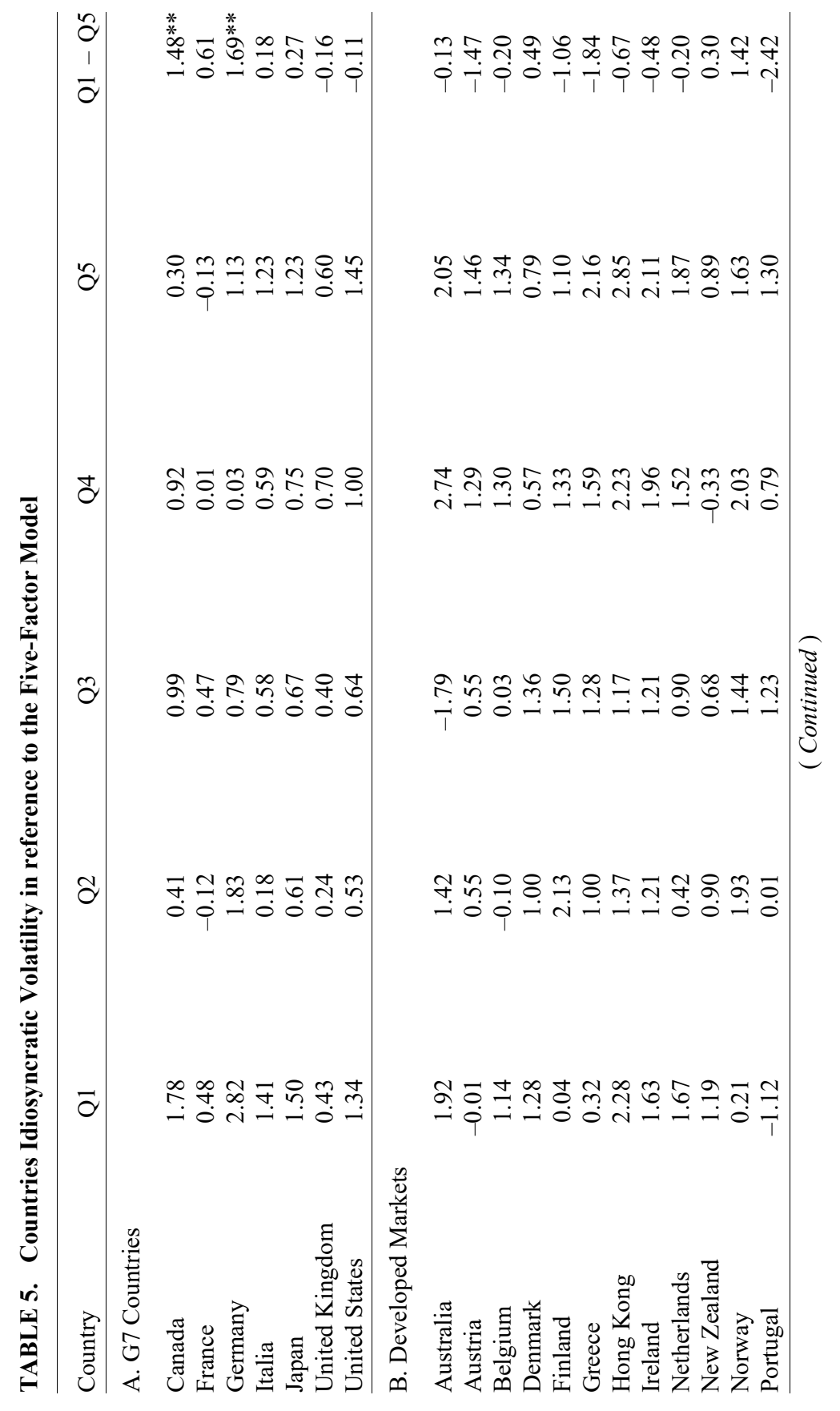




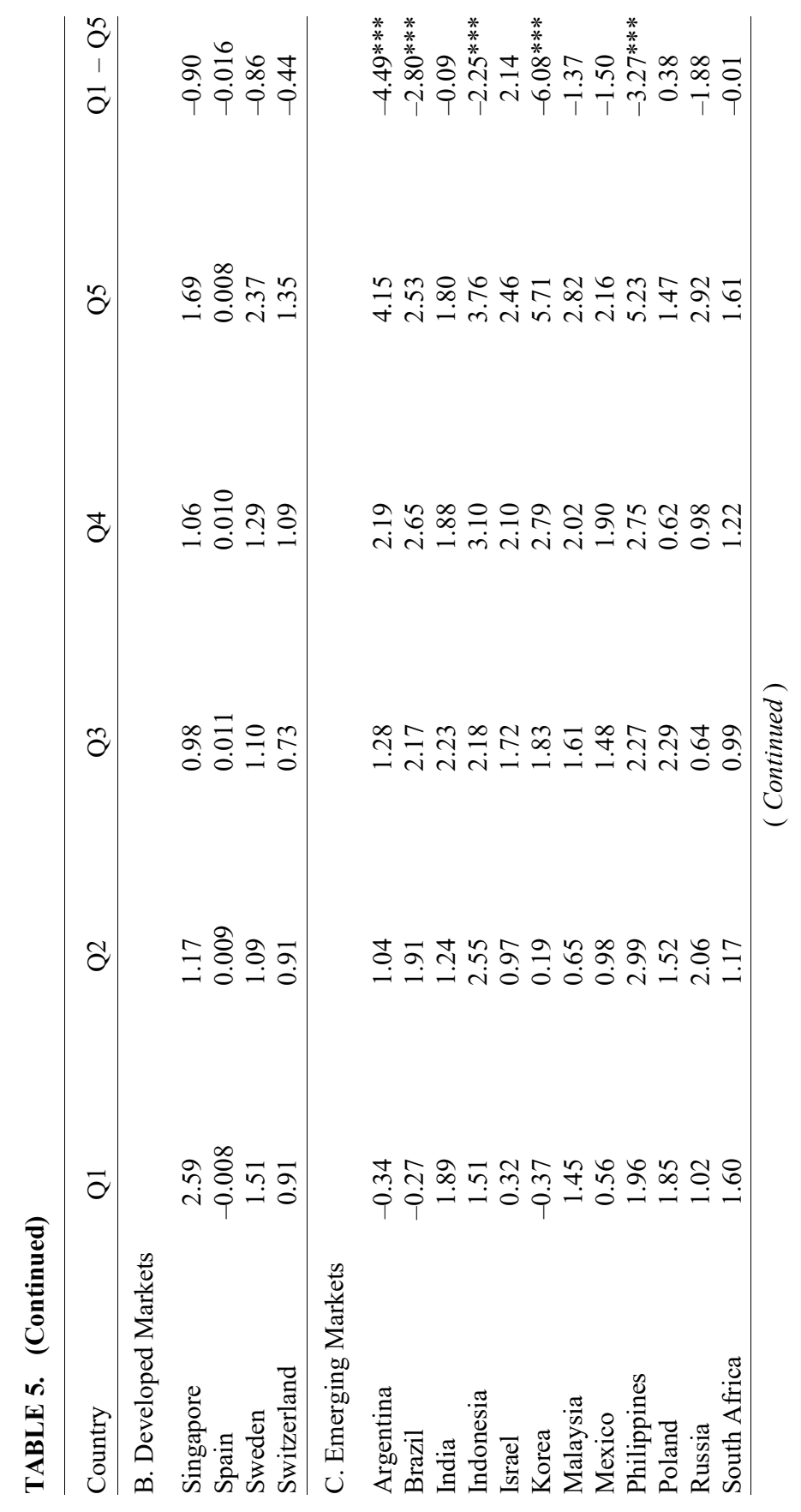




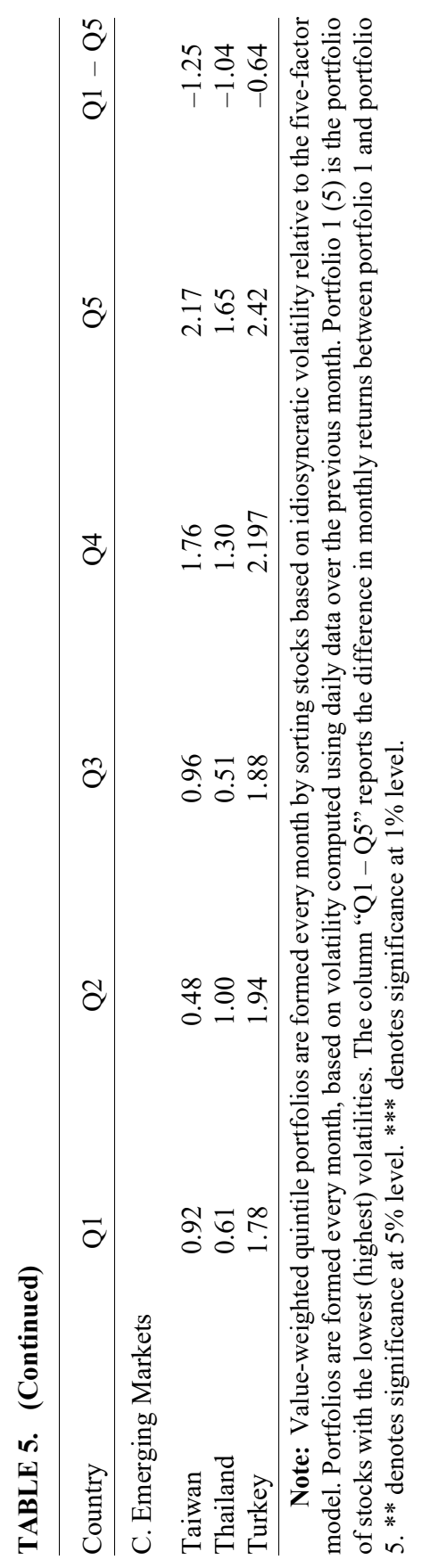




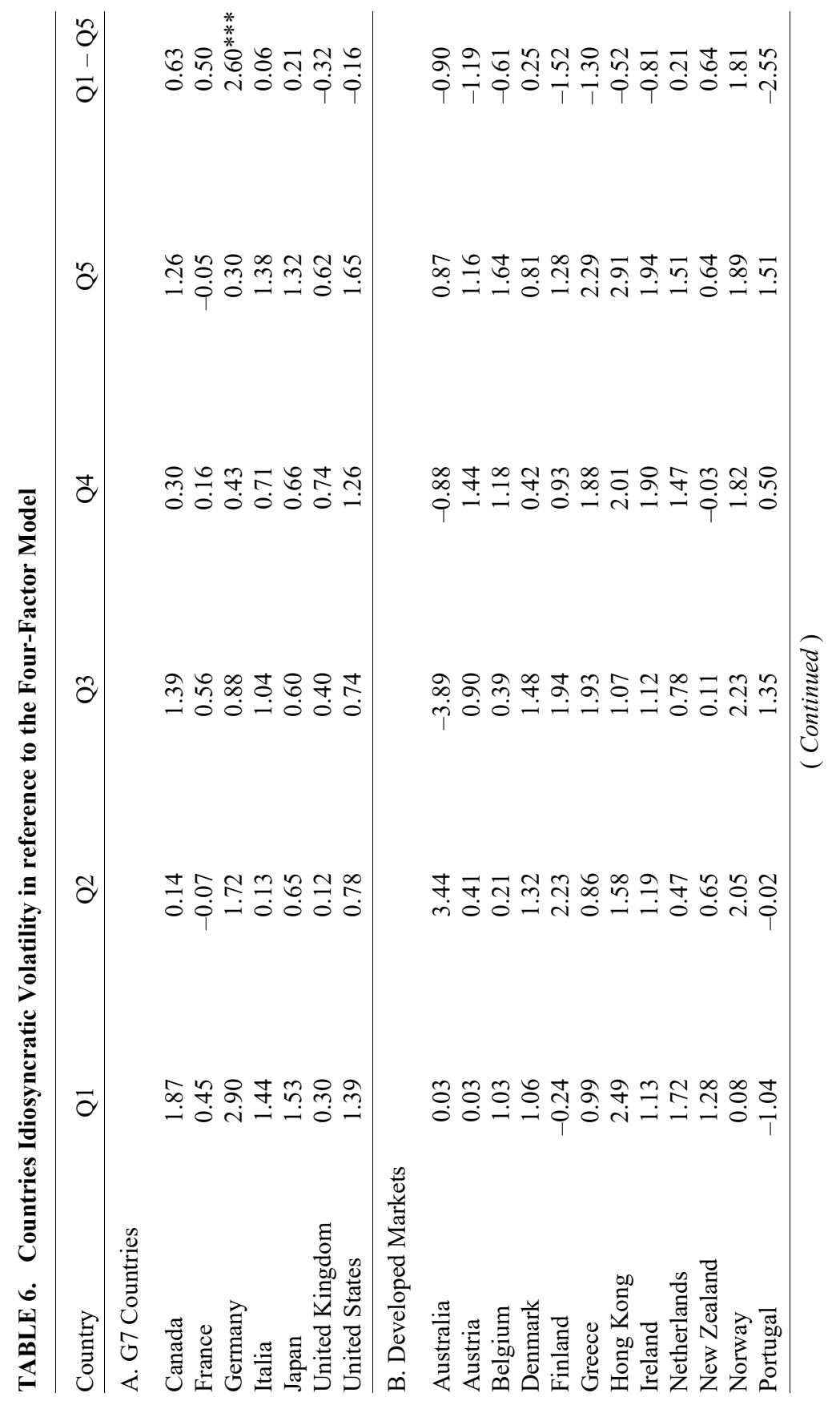


Idiosyncratic Risk and Expected Returns

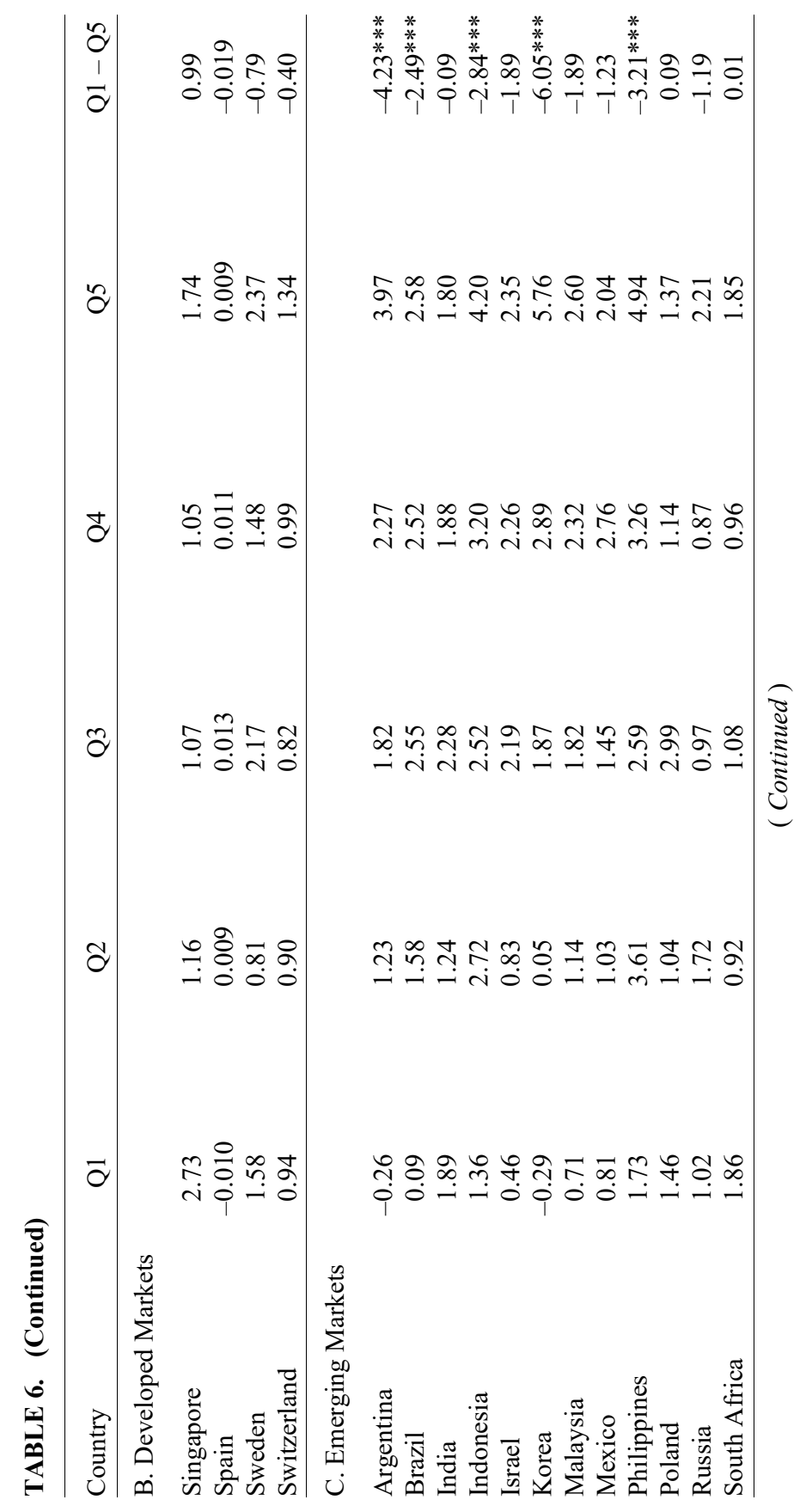




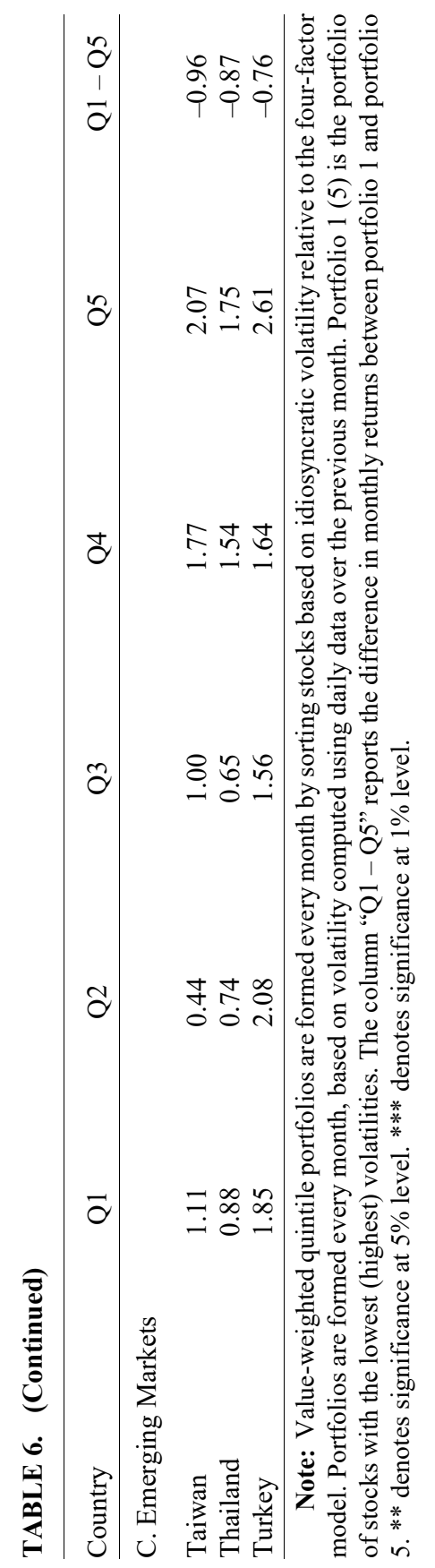




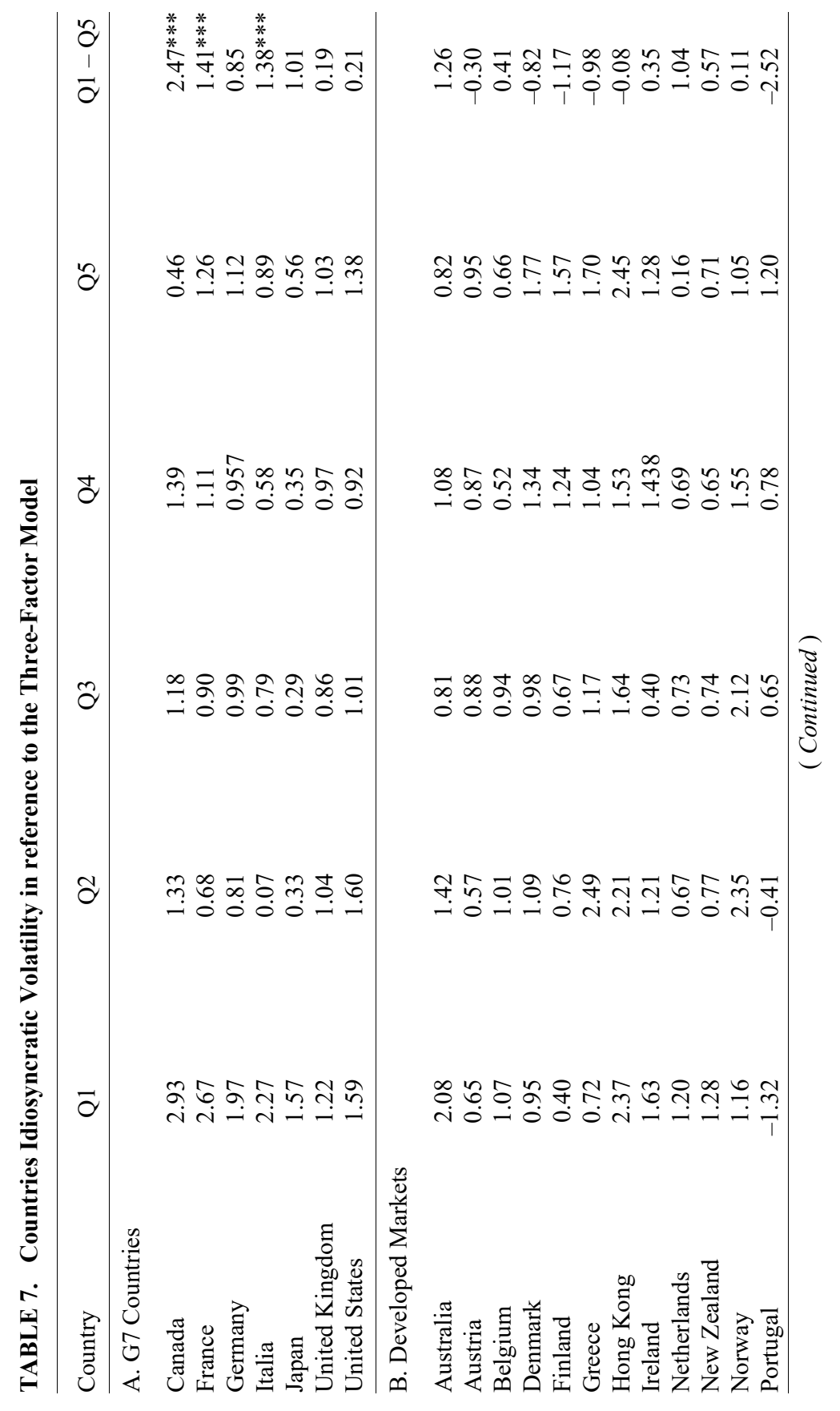




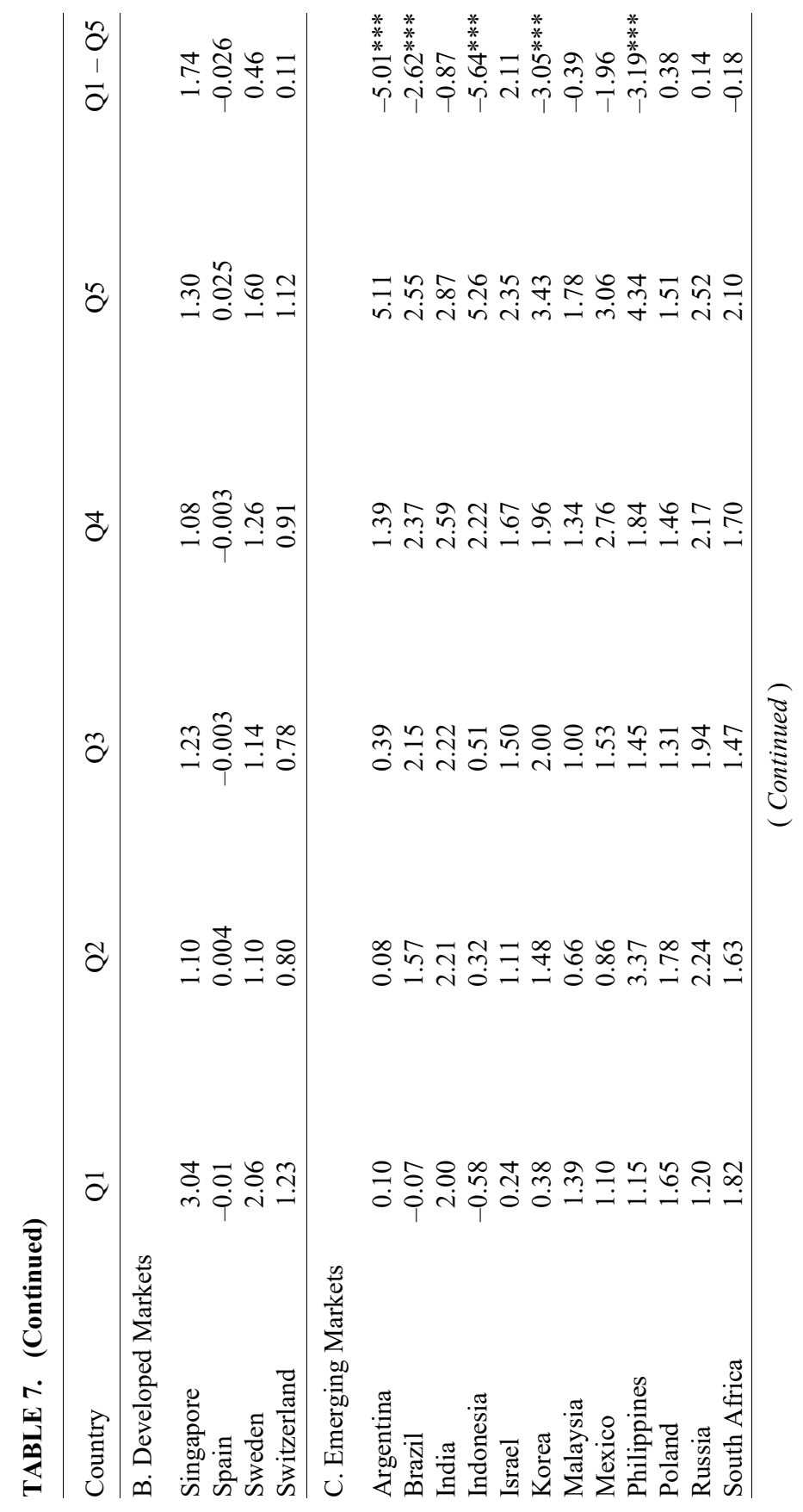




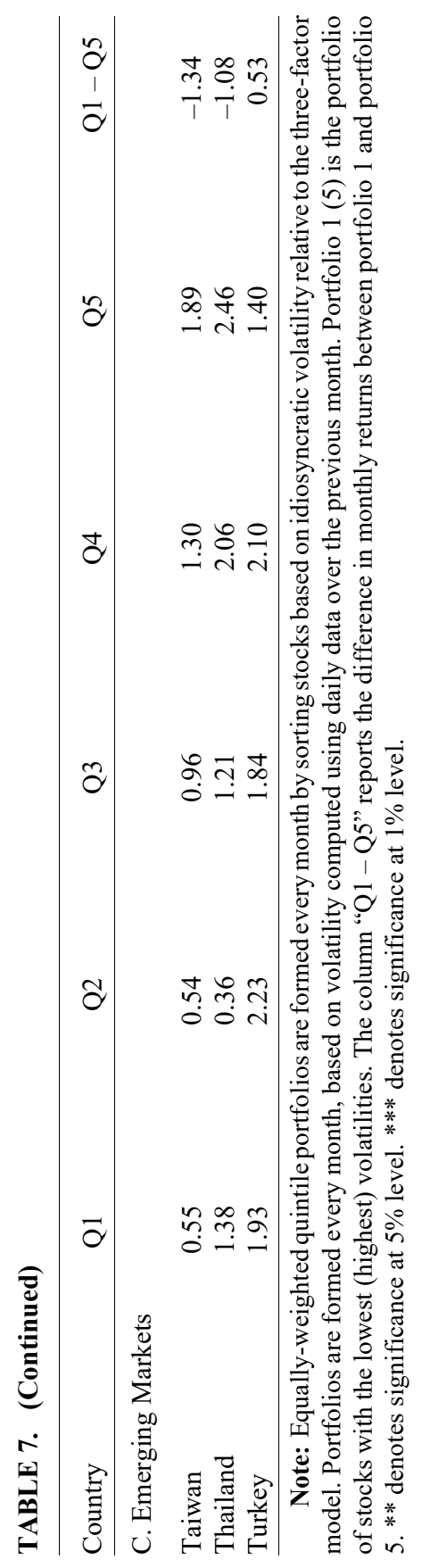




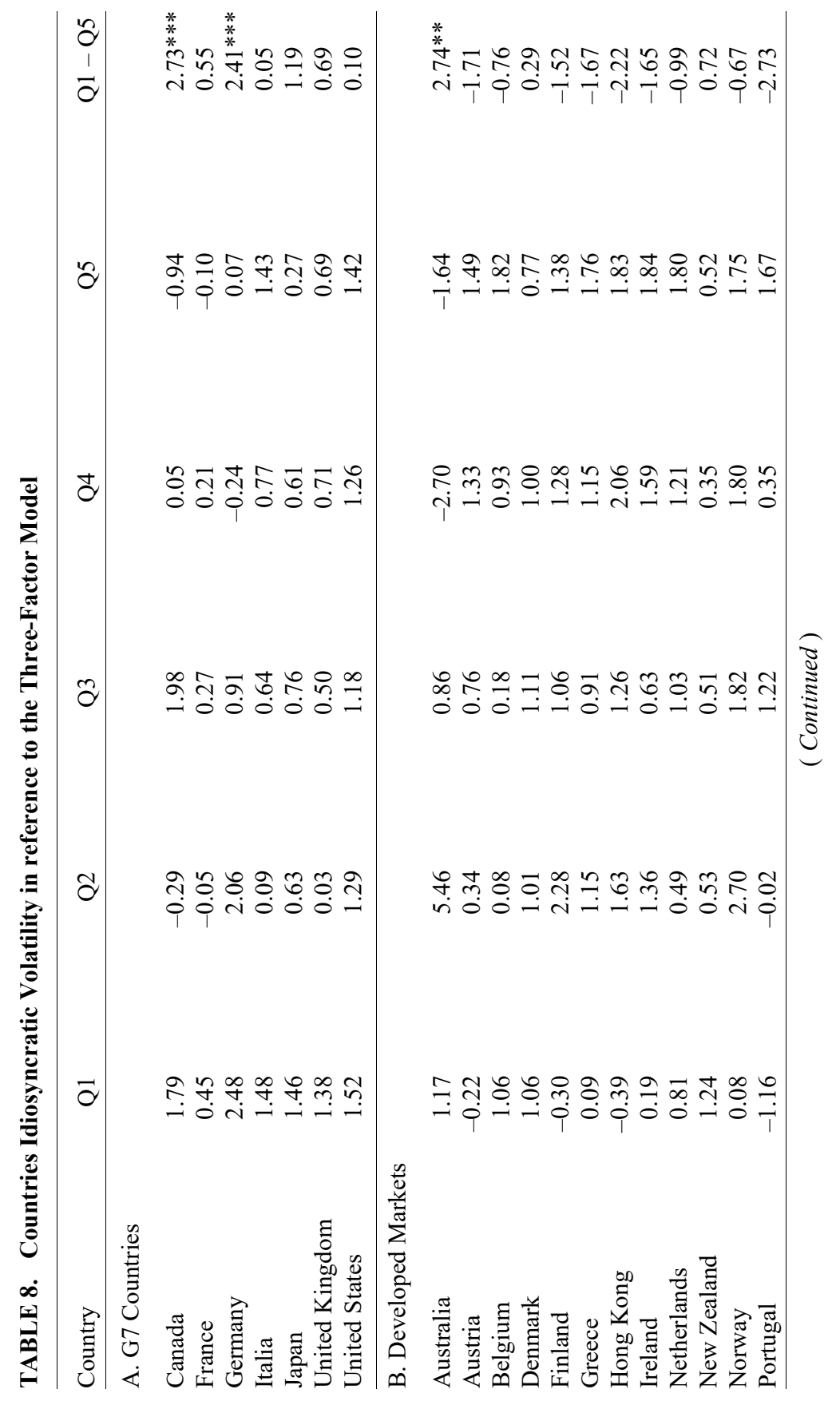




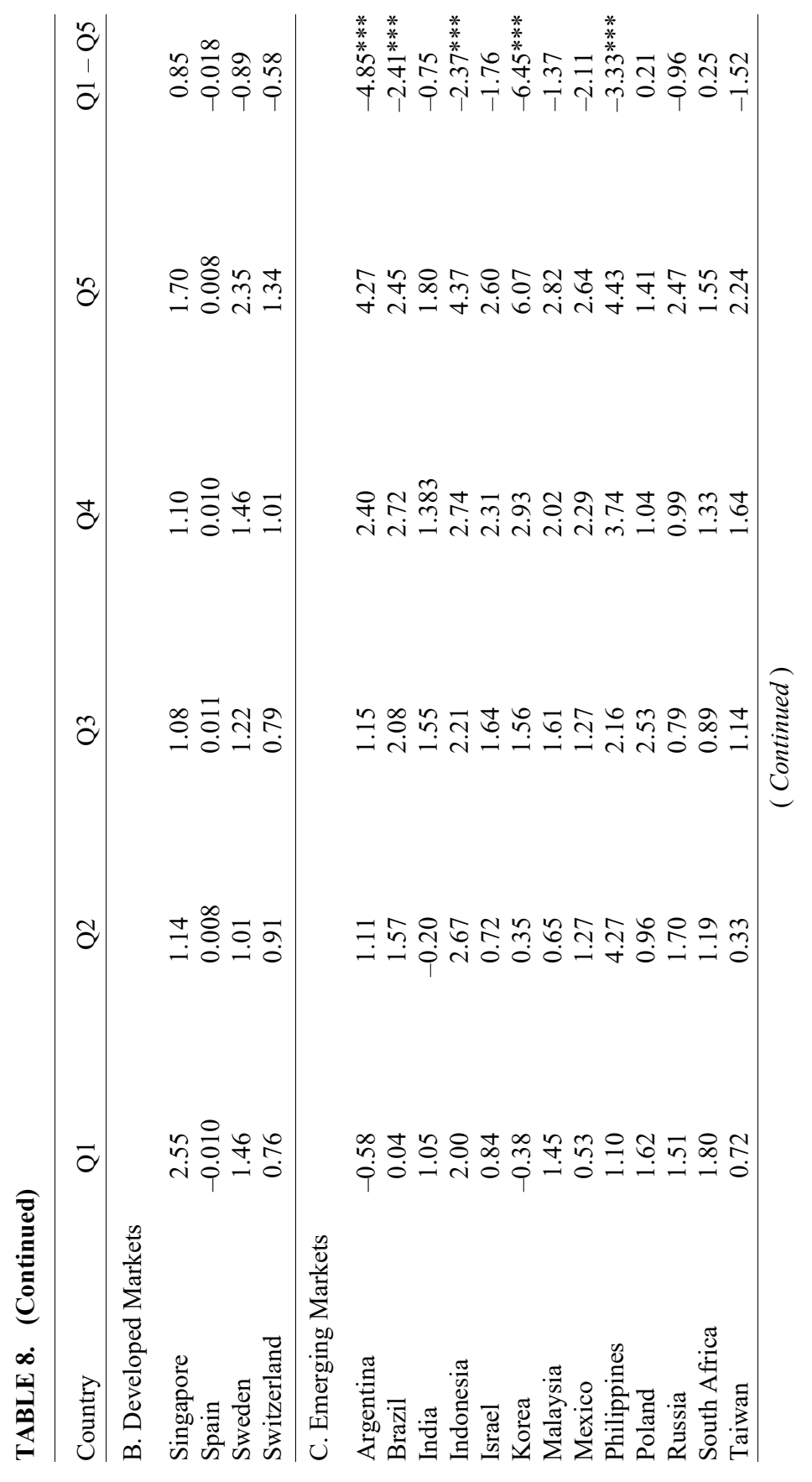




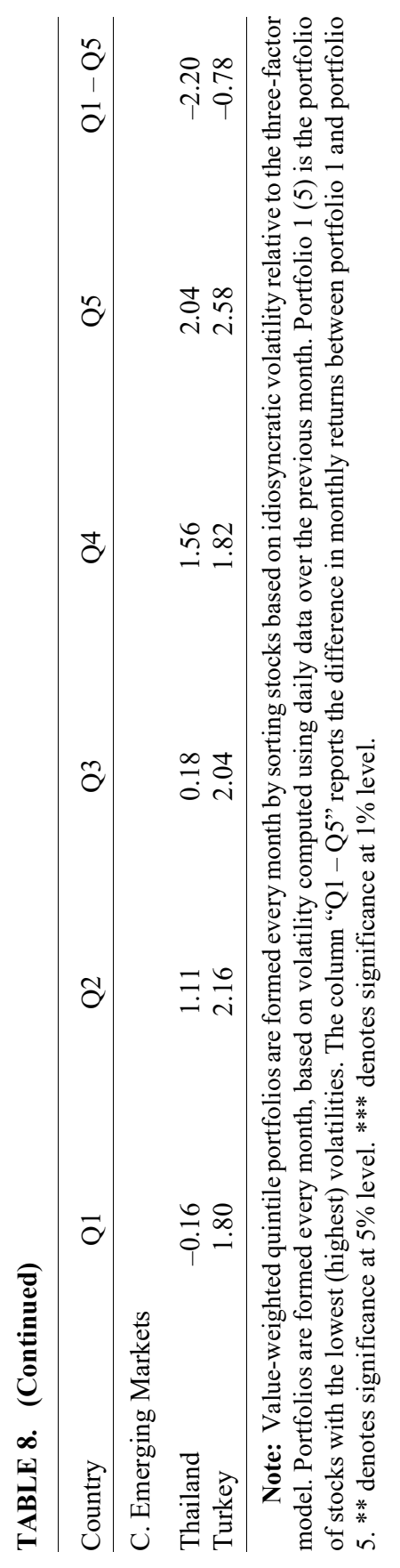




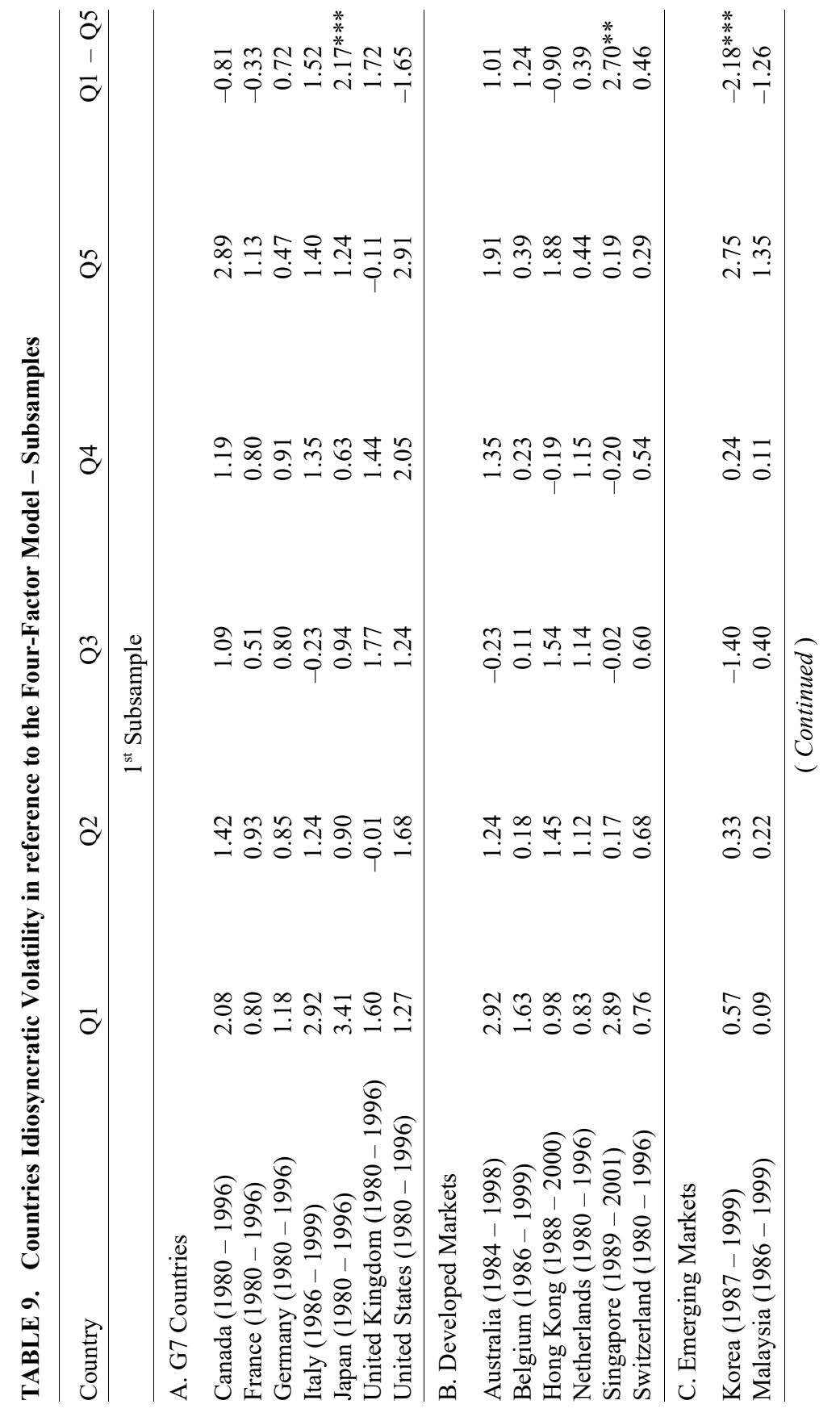




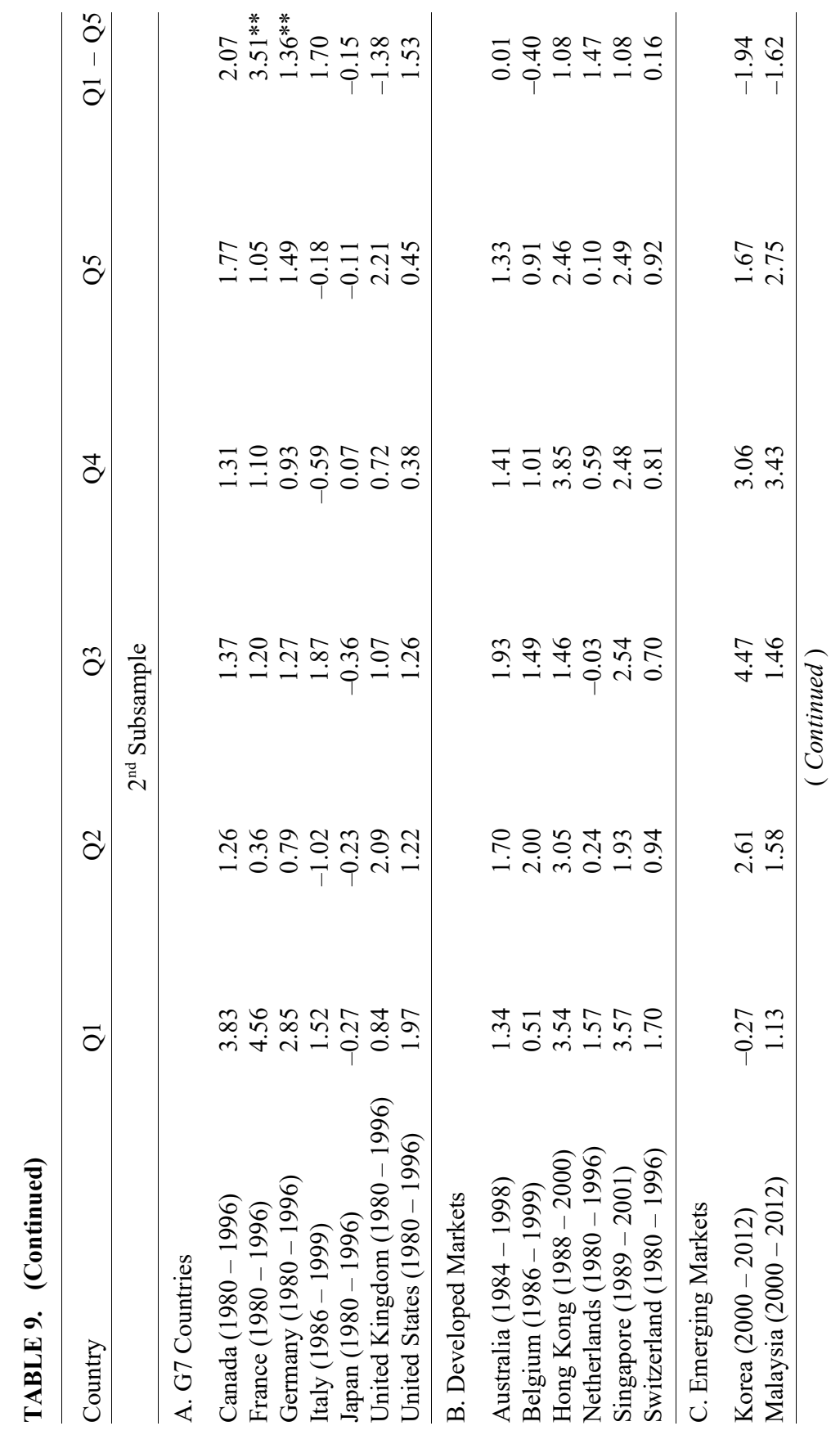




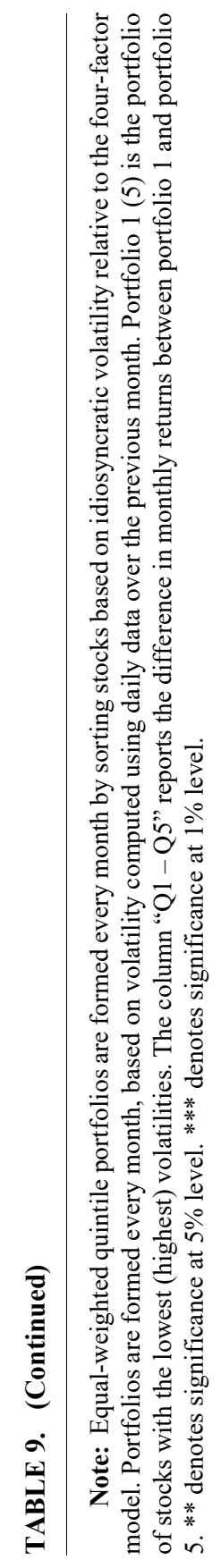


developed countries.

In panel $\mathrm{C}$ of tables 7 and 8 , the results when idiosyncratic volatility is estimated in respect to the three-factor model remain again similar to the ones exhibited in tables 3 to 6: Most of the emerging markets provide evidence of a positive relationship (11 and 13 for equal- and value-weighted portfolios respectively) and 5 out of these 15 countries imply a statistically strong association.

In summary, the relation between idiosyncratic risk and expected returns when idiosyncratic volatility is estimated using the five and four-factor models is ambiguous. For equal-weighted portfolios, a strong and negative relationship is observed for 3 of the G7 countries: France, Germany and Japan, an idiosyncratic volatility trading strategy of going long on low idiosyncratic volatility stocks and short on high idiosyncratic stocks can generate economically and statistically significant trading profits. For value-weighted portfolios, this same trading strategy would be profitable for Canada and Germany only.

While developed markets present insignificant mixed results, some emerging markets ( 5 out of 16 countries) provide evidence of a strong positive relation between expected returns and past idiosyncratic volatility. For these countries, an investment strategy of buying high idiosyncratic volatility stocks and shorting low idiosyncratic volatility stocks could result in significant trading profits.

The majority of the countries analyzed in this paper (2, 3 or 4 of the G7 countries depending on the weighting, all developed countries and 11 of the 16 emerging markets) present no evidence of a relationship between diversifiable risk and expected returns. These findings are in contrast to the ones observed by Ang et al. (2009) in which all countries in their study show a negative correspondence between idiosyncratic volatility and expected returns.

\section{Conclusion}

This study examines the role of idiosyncratic risk in an international context motivated by the study of Ang et al. (2006) that reveals the presence of an abnormal negative relationship between realized idiosyncratic volatility and subsequent 1 -month stock returns. This negative relationship has been successively denoted to in the literature 
as the 'idiosyncratic volatility puzzle' with the possibility that this anomaly might be international following evidence reported by Ang et al. (2009) in the US and 22 other developed markets. The Ang et al. (2006) framework is expanded to estimate the impact of idiosyncratic risk in international stock markets using two additional asset pricing models to estimate diversifiable risk i.e. the Carhart four-factor model as well as the five-factor model (four-factor model plus the Amihud liquidity factor).

The results obtained suggest that idiosyncratic risk does not play a role on stock returns for the 16 developed markets analyzed. While some evidence of a negative link between idiosyncratic risk is shown, the relation is statistically significant for only a few of the G-7 countries in the analysis. Indeed, only Germany shows a monotonic negative relationship between idiosyncratic volatility and stock market returns, consistent with Koch (2010). It may be the case that this is due to the fact that equity markets are still not well developed in Germany, which persists as one of the most bank-based financial systems relative to other countries in the G-7. The relatively "thinner" equity market of German firms may in part explain the idiosyncratic volatility puzzle for Germany. Providing a more thorough and rational explanation of this result remains a matter for future research. We do note, on the other hand, that idiosyncratic volatility is positively related to future expected returns for 5 out of 15 emerging market countries.

The findings related to emerging countries are consistent with investor under-diversification (e.g., Levy (1978); and Merton (1987)) wherein investors request a premium for taking idiosyncratic risk. This under- diversification may be due to informational efficiencies, although liquidity risk per se does not seem to be a driving factor in explaining the divergent results between developed and emerging markets.

Accepted by: P.C.Andreou, PhD, Editor-in-Chief(Pro-Tem), February 2015 


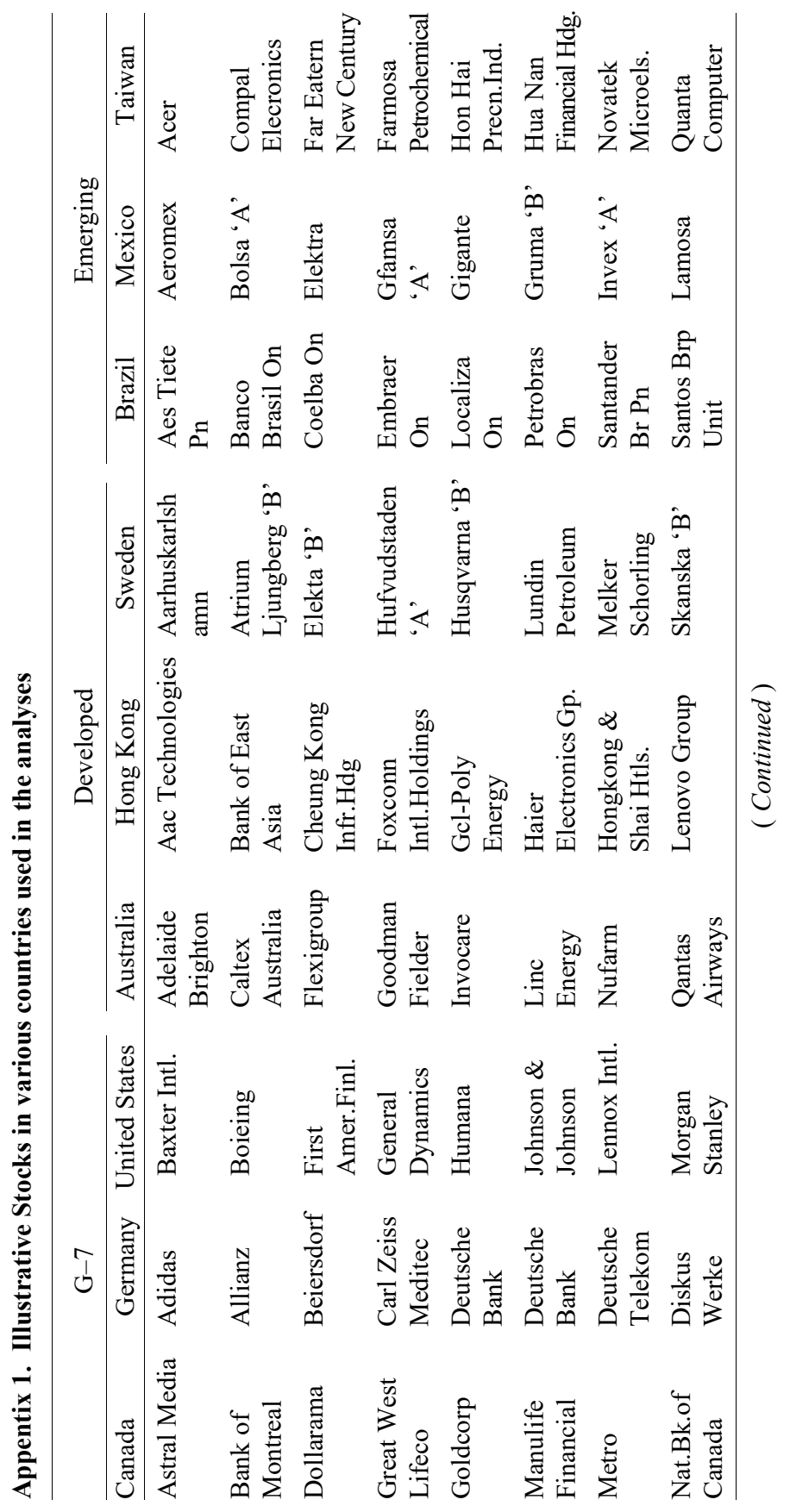




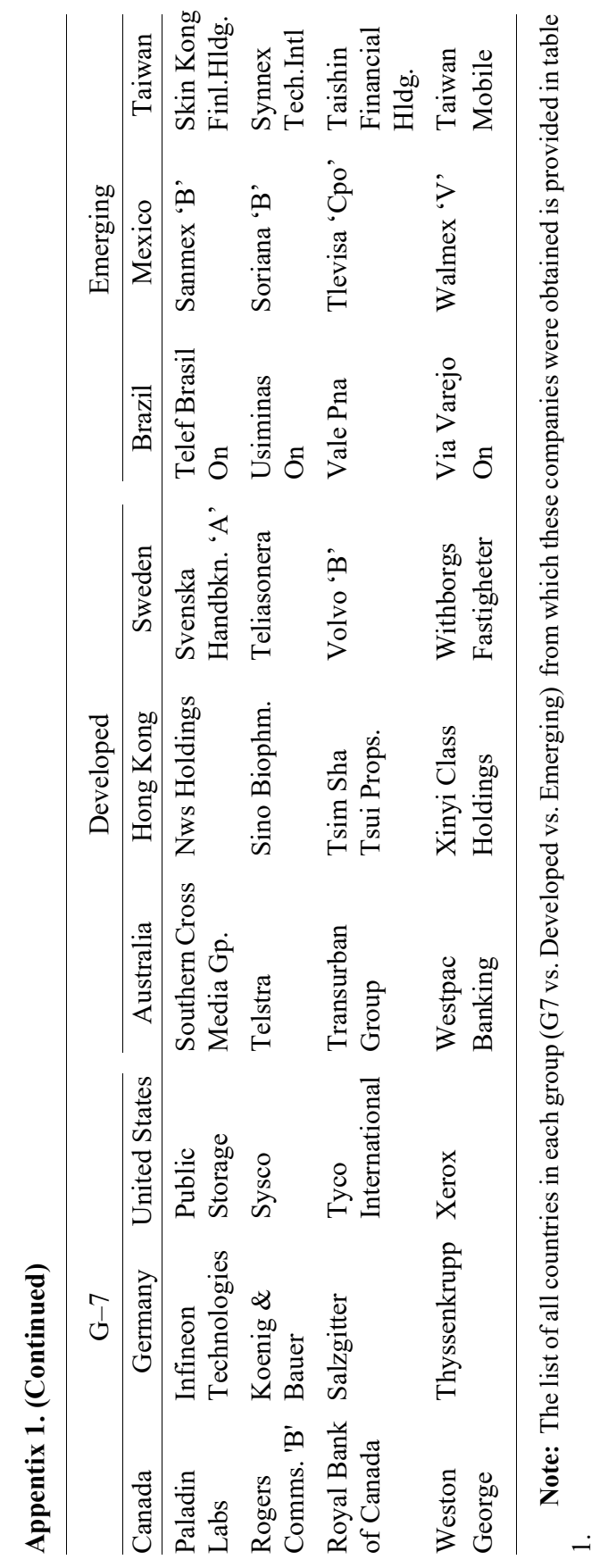




\section{Appendix 2: Equal-Weighted Portfolio Returns Sorted According to Idiosyncratic Volatilities}

A. G7 Countries
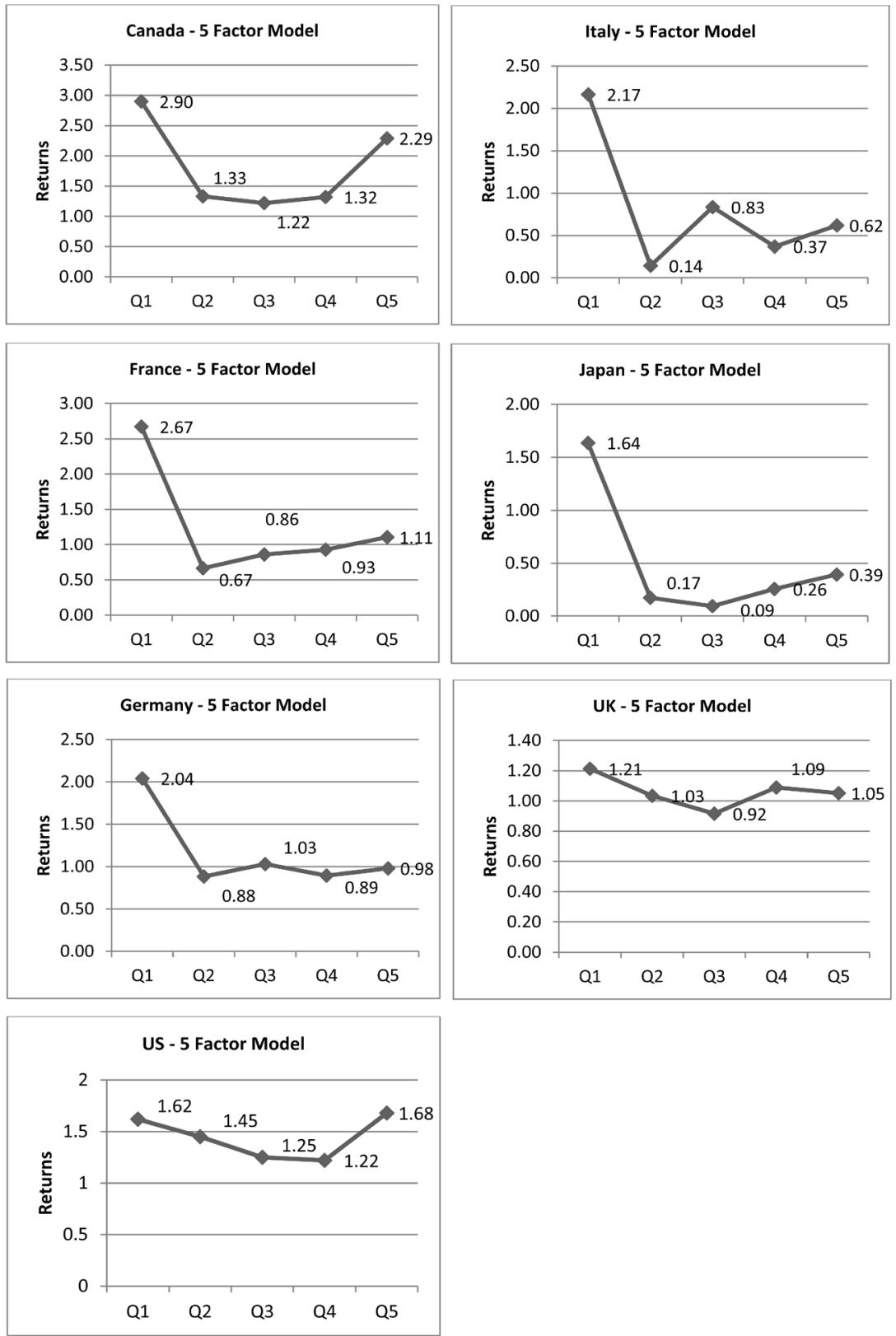


\section{B. Other Developed Countries}
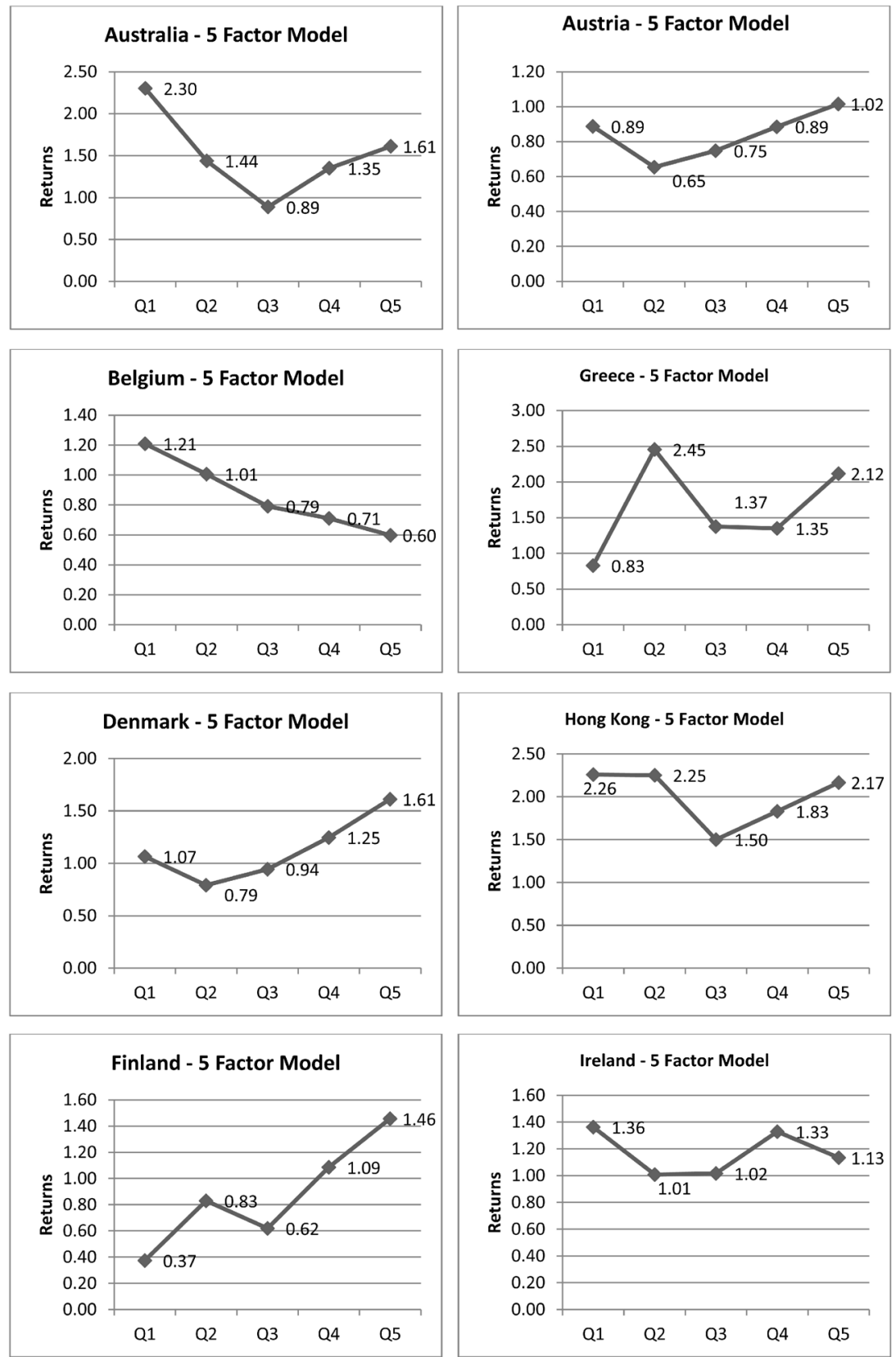
Multinational Finance Journal
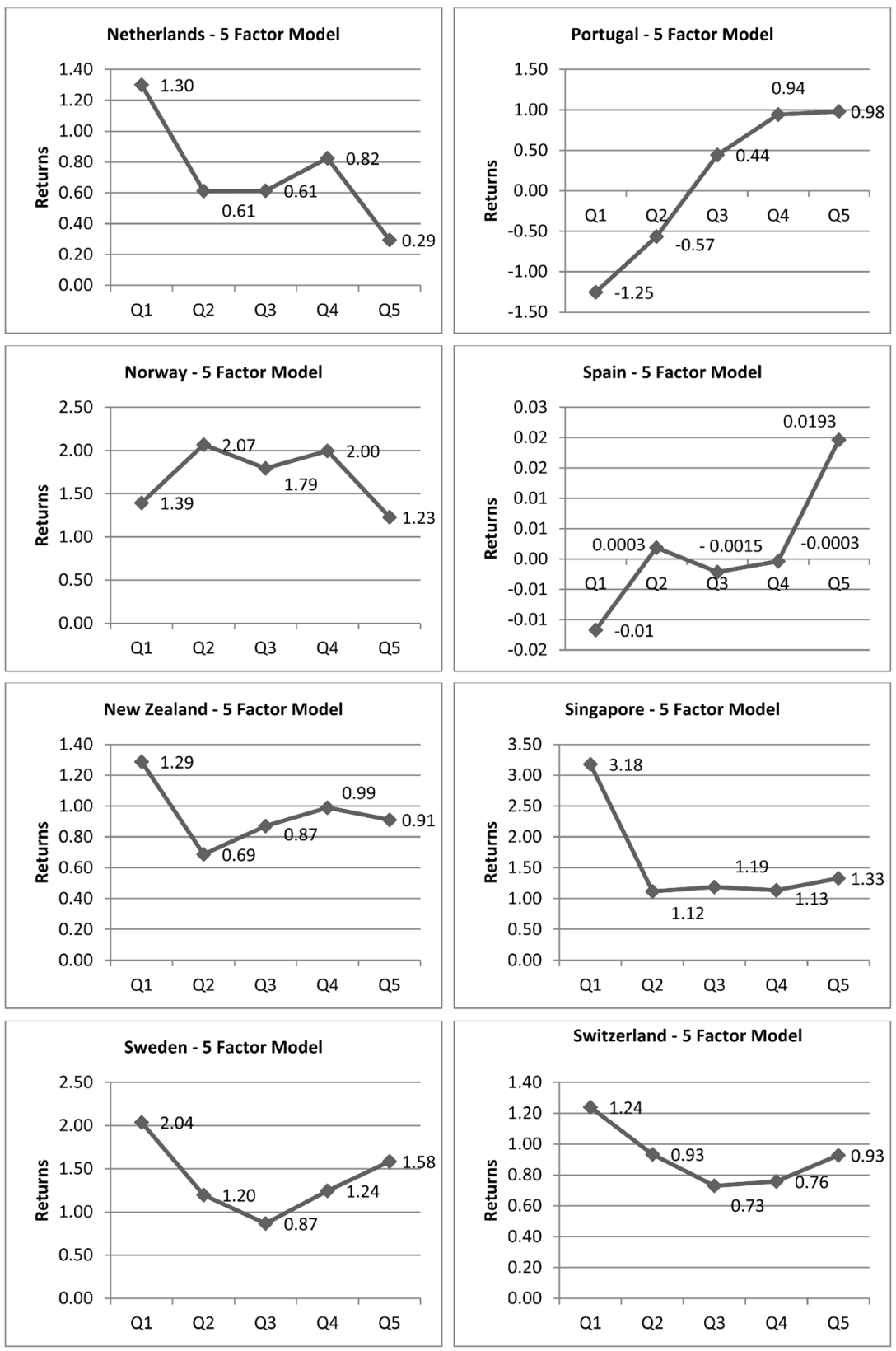


\section{Emerging Countries}
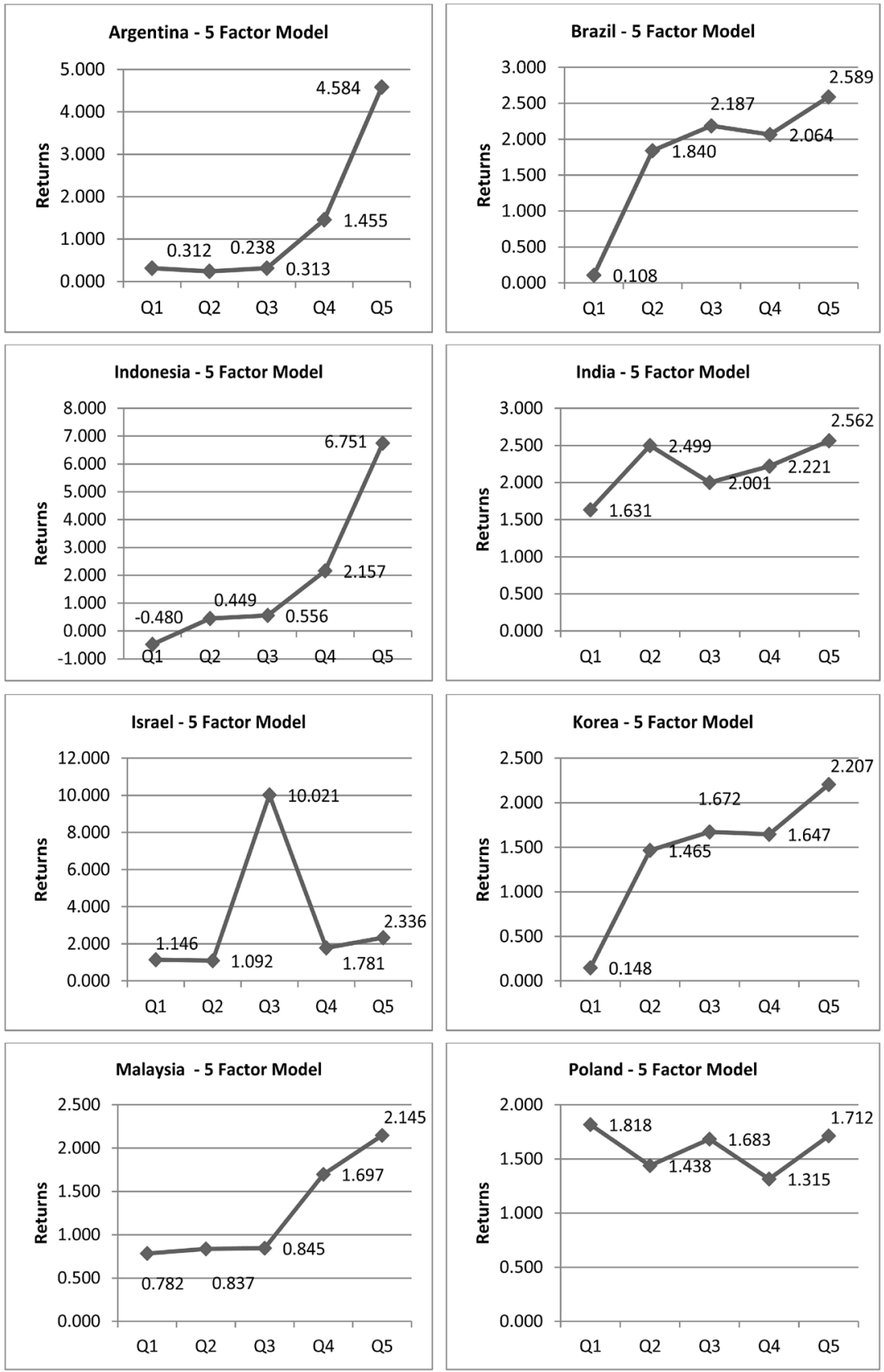

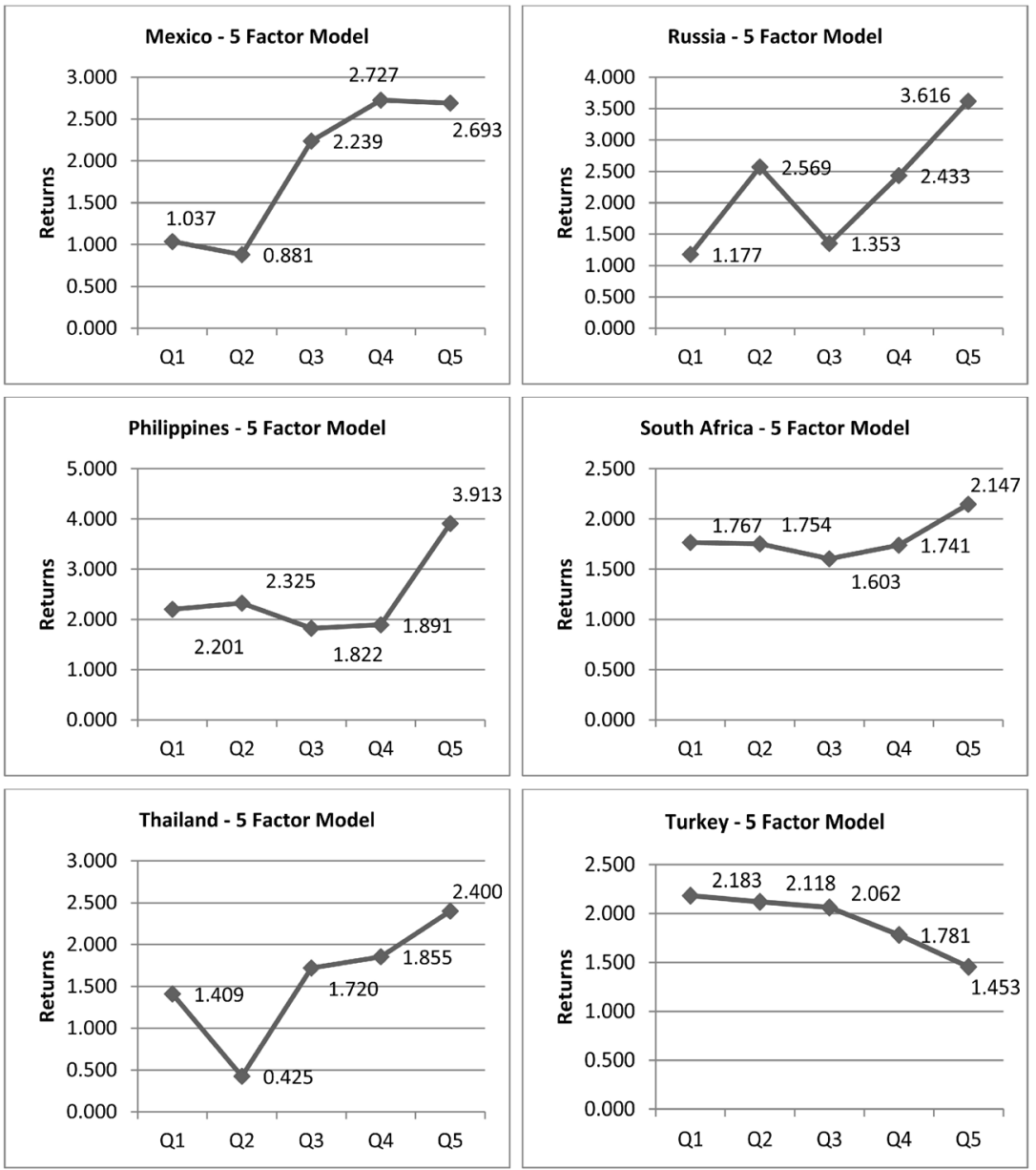

\section{References}

Amihud, Y. 2002. Illiquidity and stock returns: cross-section and time-series effects. Journal of Financial Markets 5: 31-56.

Amihud, Y., and Mendelson, H. 1986. Asset pricing and the bid-ask spread. Journal of Financial Economics 17: 223-249.

Amihud, Y.; Mendelson, H.; and Lauterbach, B. 1997. Market microstructure and securities values: Evidence from the Tel Aviv stock exchange. Journal of Financial Economics 45, 365-390.

Ang, A.; Hodrick, R. J.; Xing, Y.; and Zhang, X. 2006. The cross-section of volatility and expected returns. Journal of Finance 61: 259-299.

Ang, A.; Hodrick, R. J.; Xing, Y.; and Zhang, X. 2009. High idiosyncratic 
volatility and low returns: international and further U.S. evidence. Journal of Financial Economics 91: 1-23.

Bainbridge, C., and Galagedera, D. U. A. 2009. Relative performance of equity markets: An assessment in the conventional and downside frameworks. International Journal of Business 14: 22-45.

Bali, T. G., and Cakici, N. 2006. Aggregate idiosyncratic risk and market returns. Journal of Investment Management, 4(4).

Bali, T. G., and Cakici, N. 2008. Idiosyncratic volatility and the cross-section of expected returns. Journal of Financial and Quantitative Analysis, 43(1), 29.

Bali, T. G.; Cakici, N.; Yan, X. S.; and Zhang, Z. 2005. Does idiosyncratic risk really matter? Journal of Finance, 60: 905-929.

Bartram, S.; Brown. G.; and Stulz, R. 2012. Why are U.S. stocks more volatile? Journal of Finance 67: 1329-1370.

Bekaert, G. 1995. Market integration and investment barriers in emerging equity markets. World Bank Economic Review 9, 75- 107.

Bekaert, G.; Erb, C. B.; Harvey, C. R.; and Viskanta, T. E. 1997. What matters for emerging market investments? Emerging Markets Quarterly 1: 17-46.

Bekaert, G.; Harvey, C. R.; and Lundblad, C. 2003. Equity market liberalization in emerging markets. Journal of Financial Research 26: 275-299.

Bekaert, G.; Harvey, C.; and Lundblad, C. 2007. Liquidity and expected returns: Lessons from emerging markets. Review of Financial Studies 6: 1783-1831.

Bekaert, G.; Hodrick, R. J.; and Zhang, X. 2010. Aggregate idiosyncratic volatility. Unpublished Working Paper. Columbia University.

Ben-David, I.; Franzoni, F.; and Moussawi, R. 2012. Hedge fund stock trading in the financial crisis of 2007-2008. Review of Financial Studies 25:1-54.

Bhattacharya, U.; Daouk, H.; Jorgenson, B.; and Kehr, C. H. 2000. When an event is not an event: The curious case of an emerging market. Journal of Financial Economics 55: 69- 101.

Brennan, M. J., and Subrahmanyam, A. 1996. Market microstructure and asset pricing:on the compensation for illiquidity in stock returns. Journal of Financial Economics 41, 441-464.

Brooks, C.; Xiafei L.; and Miffre, M. 2013. Idiosyncratic risk and the pricing of poorly-diversified portfolios. International Review of Financial Analysis 30:78-85.

Brown, G., and Kapadia N. 2007. Firm-specific risk and equity market development. Journal of Financial Economics 84: 358-388.

Campbell, J. Y.; Lettau, M.; Malkiel, B. G.; and Xu, Y. 2001. Have individual stocks become more volatile? An empirical exploration of idiosyncratic risk. Journal of Finance 56:1-43.

Carhart, M. 1997. On the persistence of persistence in mutual fund performance, Journal of Finance 52: 57-82.

Carrieri, F; Chaieb, I.; and Errunza, V. 2013. Do implicit barriers matter for globalization? Review of Financial Studies 26: 1694-1739. 
Chang, E. C., and Dong, S. 2006. Idiosyncratic volatility, fundamentals, and institutional herding: Evidence from the Japanese stock market. Pacific-Basin Finance Journal 14: 135-154.

Cheng, S., and Shiu. C. 2007. Investor protection and capital structure: international evidence, Journal of Multinational Financial Management 17: $30-44$.

Chordia, T.; Roll, R.; and Subrahmanyam, A. 2001, Market liquidity and trading activity. Journal of Finance 56: 501-530.

Chordia, T.; Huh, S. W.; and Subrahmanyam, A. 2009. Theory-based illiquidity and asset pricing. Review of Financial Studies 22: 3629-3668.

Clark, E., and Tunaru, R. 2001. Emerging markets: investing with political risk. Multinational Finance Journal 5: 155-173.

Denis, D. K., and McConnell, J. J. 2003. International corporate governance. Journal of Financial and Quantitative Analysis 38: 1-36.

Fama, E. F., and French, K. R. 1988. Dividend yields and expected stock returns. Journal of Financial Economics 22: 3-25.

Fama, E. F., and French, K. R. 1992. The cross-section of expected stock returns. Journal of Finance 47: 427-465.

Fama, E. F., and French, K. R. 1993. Common risk factors in the returns on stocks and bonds. Journal of Financial Economics 33: 13-56.

Fama, E. F., and French, K. R. 1995. Size and book-to-market factors in earning and returns. Journal of Finance 50: 131-155.

Fan, S.; Opsal, S.; and Yu, L. 2015. Equity anomalies and idiosyncratic risk. Multinational Finance Journal 19: 33-75.

Fu, F. 2009. Risk and the cross-section of expected stock returns. Journal of Financial Economics, 91: 24-37.

Girard, E., and Sinha, A. 2006. Does total risk matter? The case of emerging markets. Multinational Finance Journal 10: 117-151.

Goyal, A., and Santa-Clara, P. 2003. Idiosyncratic risk matters! Journal of Finance 58: 975- 1007.

Griffin, J. M. 2002. Are the Fama and French factors global or country specific? Review of Financial Studies 15:783-803.

Guo, H., and Savickas, R. 2006. The relation between time-series and cross-sectional effects of idiosyncratic variance on stock returns in G7 countries. Working paper, Federal Reserve Bank of St. Louis.

Haugen, R., and Baker, N. L. 1996. Commonality in the determinants of expected stock returns. Journal of Financial Economics 41: 401-439.

Huang, W.; Liu, Q.; Rhee, G.; and Zhang, L. 2010. Return reversals, idiosyncratic risk and expected returns. Review of Financial Studies 23: $147-168$.

Jones, C. M., and Rhodes-Kropf, M. 2003. The price of diversifiable risk in venture capital and private equity. Working paper. New York: Columbia University.

Koch, S. 2010. Essays in empirical asset pricing: liquidity, idiosyncratic risk, and the conditional risk-return relation, $\mathrm{PhD}$ Thesis, University of Bonn. 
La Porta, R.; Lopez-de-Silanes, F.; Shleifer, A.; and Vishny, R. W. 1998. Law and finance. Journal of Political Economy 106: 1113- 1155.

Lemmon, M. L., and Lins, K. V. 2003. Ownership structure, corporate governance, and firm value: evidence from the East Asian financial crisis. Journal of Finance 58:1445-1468.

Lesmond, D. A. 2005. The costs of equity trading in emerging markets. Journal of Financial Economics 77: 411-52.

Levy, H. 1978. Equilibrium in an imperfect market: A constraint on the number of securities in the portfolio. American Economic Review 68: 642-658.

Lins, K. V. 2003. Equity ownership and firm value in emerging markets. Journal of Financial and Quantitative Analysis 38: 159-184.

Lintner, J. 1965. The Valuation of risk asset and the selection of risk investments in stock portfolios and capital budgets. Review of Economics and Statistics 47:13-37.

Malkiel, B. G., and Xu, Y. 1995. The structure of stock market volatility. Unpublished Working Paper Princeton University FRC Memo No. 154.

Malkiel, B. G., and Xu, Y. 1997. Risk and return revisited. Journal of Portfolio Management 23:9-14.

Malkiel, B. G., and Xu, Y. 2006. Idiosyncratic risk and security returns. Princeton University \& The University of Texas at Dallas.

Merton, R. C. 1987. A simple model of capital market equilibrium with incomplete information. Journal of Finance 42: 483-510.

Markowitz, H. M. 1952. Portfolio selection. Journal of Finance 7: 77-91.

Nartea, G. V.; Ward, B. D.; and Yao, L. J. 2011. Idiosyncratic volatility and cross-sectional stock returns in Southeast Asian stock markets. Accounting and Finance 51: 1031-1054.

Pukthuanthong-Le, K., and Visaltanachoti, N. 2009. Idiosyncratic volatility and stock returns: a cross country analysis. Applied Financial Economics 19: 1269-1281.

Sharpe, W. F. 1964. Capital asset prices: A theory of market equilibrium under conditions of risk. Journal of Finance 19: 425-442.

Shleifer, A., and Vishny, R. W. 1997. A survey of corporate governance. Journal of Finance 52: 737- 783.

Stulz, R. 1981. On the effects of barriers to international investment. Journal of Finance 36: 923-934.

Switzer, L. N., and Tahaoglu, C. 2015. The benefits of international diversification: market development, corporate governance, market cap, and structural change effects. Forthcoming International Review of Financial Analysis.

Umutlu, M.; Akdeniz, L.; and Altay-Salih, A. 2010. The degree of financial liberalization and aggregated stock-return volatility in emerging markets. Journal of Banking and Finance 34: 509-552.

Wei, S. X., and Zhang, C. 2005. Idiosyncratic risk does not matter: A re-examination of the relationship between average returns and average volatilities. Journal of Banking and Finance 29: 603-621. 